\title{
Recent advances in the use of chiral aldimines in
}

\section{asymmetric synthesis}

\author{
Francisco Foubelo and Miguel Yus** \\ Departamento de Química Orgánica, Facultad de Ciencias and Centro de Innovación en Química \\ Avanzada (ORFEO-CINQA), Universidad de Alicante, Apdo. 99, E-03080 Alicante, Spain \\ Fax:+34 965903549. E-mail: yus@us.es \\ Dedicated to Professor Irina P. Beletskaya
}

Chiral $N$-(tert-butyl)sulfinyl aldimines, easily prepared from commercially available compounds, have been used as starting materials for the following processes: (a) hydrogen transfer, (b) addition of zincates, (c) In-promoted allylation, and (d) addition of zinc enolates. In all cases, the final desulfinylation to yield the expected chiral $\alpha$-substituted primary amines was easily performed with hydrochloric acid in an organic solvent. This methodology has been successfully applied to the preparation of chiral natural products such as alkaloids and amino acids.

Key words: chiral aldimines, hydrogen transfer, trialkyl zincates, indium, allylation, zinc enolates, chiral primary amines

\section{Introduction}

It is believed that the amine functionality is incorporated into more than $75 \%$ of all drugs and drug candidates, being also abundant in natural products, catalysts and materials. ${ }^{1}$ In addition, in most of the cases this type of nitrogenated compounds possesses at least one stereocenter, especially in naturally occurring products, so the discovering of general and versatile asymmetric methodologies for preparing chiral amines are of great synthetic importance. In the case of chiral $\alpha$ substituted amines the most useful procedures involve the reduction of ketimines or the addition of an organometallic compound to aldimines. ${ }^{2}$ In general, the starting imines should be protected (to prevent oligomerization) and this circumstance allows introducing an electron-withdrawing group at the nitrogen in order to activate the carbon-nitrogen double bond for the reaction with nucleophiles. Thus, in the case of $N$-sulfinyl imines the reaction with nucleophiles can yield products resulting from a $\alpha$-deprotonation (for basic nucleophiles), reduction of the carbon-nitrogen double bond (using a hydride) or 1,2-addition, this process being normally the desired one (Scheme 1). ${ }^{2}$

* This account is based in the presentation by one of the authors (MY) at the International Congress on Heterocyclic Chemistry "KOST-2015", held at the Lomonosov Moscow State University (October 18-23, 2015)

** Correspondence author. 


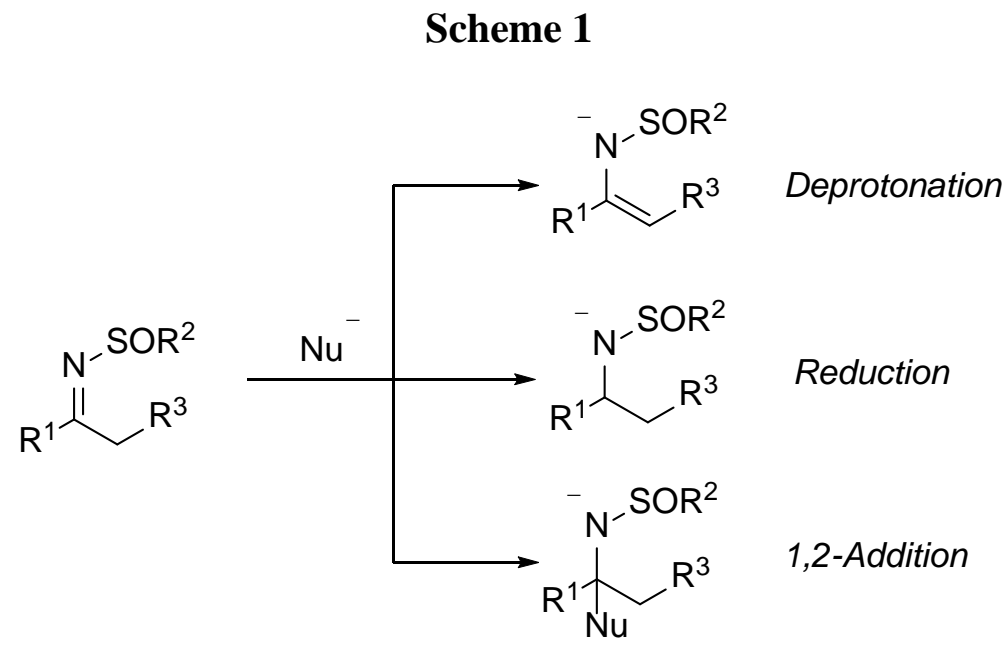

In this account the reactivity of chiral $N$-(tert-butyl)sulfinyl imines in a hydrogen transfer reaction, the reaction with zincates, their indium-promoted allylation, as well as the reaction with zinc-enolates in a multicomponent process will be considered.

\section{Hydrogen transfer to chiral $N$-(tert-butyl)sulfinyl imines}

Although the asymmetric transfer hydrogenation to ketones has been already reported as an excellent procedure to achieve chiral secondary alcohols, ${ }^{3}$ the application of this methodology to the corresponding imines has been far less explored. ${ }^{4}$ The main advantage of this technology is the use of a safe source of hydrogen, usually isopropanol, so avoiding the use of hazardous molecular hydrogen or metal hydrides. Thus, we applied the ruthenium-catalyzed hydrogen transfer to chiral $N$-(tert-butyl)sulfinyl imines ${ }^{5}$ using isopropanol and a catalytic amount of a chiral amino indanol ${ }^{6}$ under basic conditions. Scheme 2 shows the match combination of both chiral components. The reaction was followed by a deprotection of the nitrogen atom to yield the corresponding primary amines with high yields and enantioselectivities. ${ }^{7}$ 


\section{Scheme 2}<smiles>[R]C([R])=NS(=O)C(C)(C)C</smiles>

1. $\left[\mathrm{RuCl}_{2}(P \text {-cymene })\right]_{2}(5 \%)$<smiles>NCN</smiles>

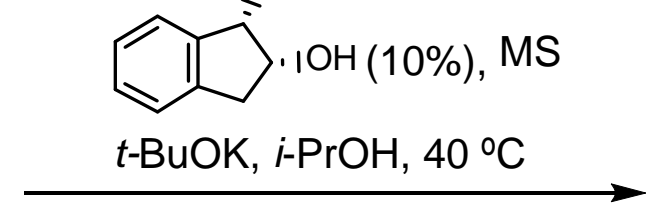

2. $\mathrm{HCl}, \mathrm{MeOH}$<smiles>[R]C([R])N</smiles><smiles>C[C@H](N)c1ccccc1</smiles>

99\% $(98 \%$ ee $)$<smiles>C[C@H](N)c1ccc([N+](=O)[O-])cc1</smiles>

$(97 \%$ ee)<smiles>C[C@H](N)C1CCCCC1</smiles>

$82 \%$

$(69 \%$ ee)<smiles></smiles>

(>98\% ee)<smiles>C[C@H](N)c1ccc2ccccc2c1</smiles>

96\% $(98 \%$ ee)<smiles>C[C@H](N)c1ccccc1</smiles>

Actually, since a source of asymmetric information is already present in the starting imine, the use of an achiral aminoalcohol seems not to be necessary. That is the case so, after trying several ligands, 2-amino-2-methyl-1-propanol showed to be the most efficient under the same reaction conditions given in Scheme 2. The corresponding primary amines were obtained after final acidic treatment (Scheme 3 and Chart 1$)^{8}$ 


\section{Scheme 3}<smiles>[R]C([R])=NS(=O)C(C)(C)C</smiles>

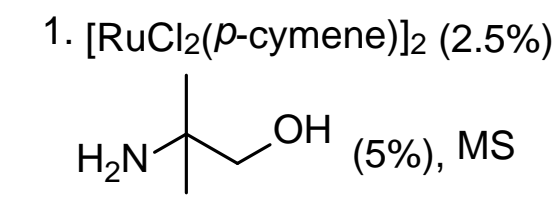

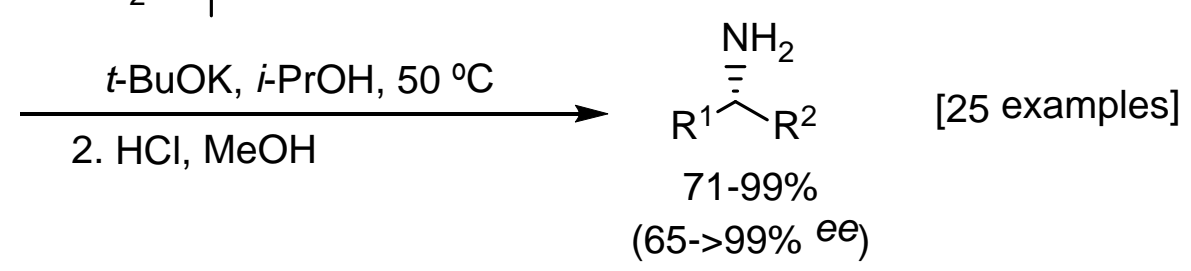

$\mathrm{R}^{1}=i-\mathrm{Pr}, t-\mathrm{Bu}, \mathrm{Ph}, 2-\mathrm{MeC}_{6} \mathrm{H}_{4}, 3-\mathrm{MeOC}_{6} \mathrm{H}_{4}, 4-\mathrm{MeOC}_{6} \mathrm{H}_{4}, 4-\mathrm{BocNHC}_{6} \mathrm{H}_{4}, 2-\mathrm{ClC}_{6} \mathrm{H}_{4}, 3-\mathrm{ClC}_{6} \mathrm{H}_{4}$ ' 4- $\mathrm{ClC}_{6} \mathrm{H}_{4}, 4-\mathrm{CF}_{3} \mathrm{C}_{6} \mathrm{H}_{4}, 4-\mathrm{NO}_{2} \mathrm{C}_{6} \mathrm{H}_{4}$, 1-naphthyl, 2-naphthyl, 2-furyl, 2-thienyl, $\mathrm{Ph}\left(\mathrm{CH}_{2}\right)_{2}$ $\mathrm{R}^{2}=\mathrm{Me}, \mathrm{Et}, n_{-} \mathrm{Pr}, i-\mathrm{Pr}, n_{-} \mathrm{Bu}, \mathrm{Cy},(E)-\mathrm{PhCH}=\mathrm{CH}$

As expected, the same chemistry applied to the enantiomeric starting imines gave the corresponding enantiomeric primary amines with similar results (Scheme 4 and Chart 1). ${ }^{8}$

\section{Scheme 4}

1. $\left[\mathrm{RuCl}_{2}(p \text {-cymene })\right]_{2}(2.5 \%)$<smiles>[R]C([R])=NS(=O)C(C)(C)C</smiles><smiles>CC(C)(N)CO</smiles>

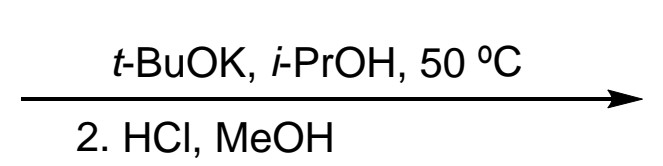<smiles>[R]C([R])N</smiles>

[2 examples]

$$
\left[\mathrm{R}^{1}=\mathrm{Ph}, 3-\mathrm{MeOC}_{6} \mathrm{H}_{4} ; \mathrm{R}^{2}=\mathrm{Me}\right]
$$

96-99\%

$(97-98 \%$ ee) 


\section{Chart 1}<smiles>C[C](N)c1ccccc1</smiles>

$97 \%$

(97\% ee)<smiles>Cc1ccccc1[C@H](C)N</smiles>

99\%

(95\% ee)<smiles>C[C](N)C(C)C</smiles>

99\%

$(98 \%$ ee)<smiles>CC[C@H](N)c1ccccc1</smiles>

$98 \%$

(98\% ee)<smiles>C[C@H](N)c1cccc(Cl)c1</smiles>

99\%

(96\% ee)<smiles>C[C@H](N)C1CCCCC1</smiles>

$79 \%$

(>99\% ee)<smiles>CC(C)[C@H](N)c1ccccc1</smiles>

91\%

$(90 \%$ ee)<smiles>CC(N)c1ccc([N+](=O)[O-])cc1</smiles>

(98\% ee)<smiles>C[C](N)C(C)(C)C</smiles>

$71 \%$

(99\% ee)<smiles>N[C@@H](c1ccccc1)C1CCCCC1</smiles>

$84 \%$

(87\% ee)<smiles>CC(N)c1ccc2ccccc2c1</smiles><smiles>COc1cccc([C@@H](C)N)c1</smiles>

99\%

$(97 \%$ ee)

Concerning the possible mechanism of the reaction, DFT calculations for the model imine derived from acetophenone indicated that the attack of the hydrogen transfer reagent takes part, as expected, at the less hindered face of the imine that is the pro- $R$ side for imines with $R_{(\mathrm{S})}$ configuration at the sulphur atom, as it is shown in the Scheme $5 .^{8 \mathrm{~b}}$ 


\section{Scheme 5}

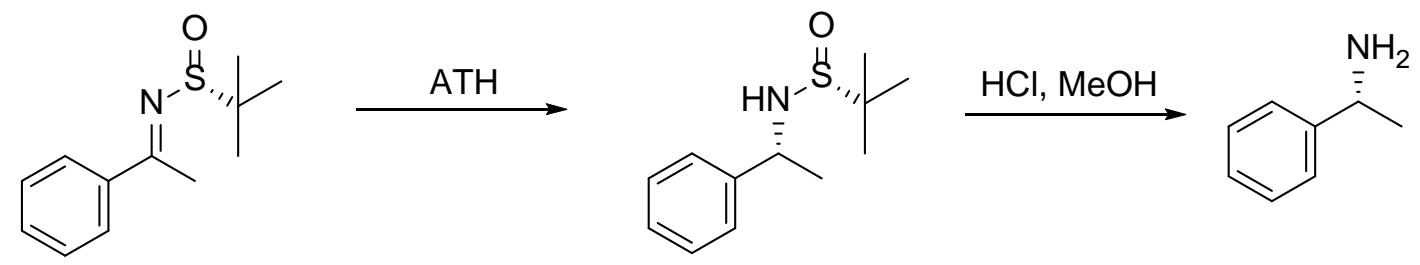

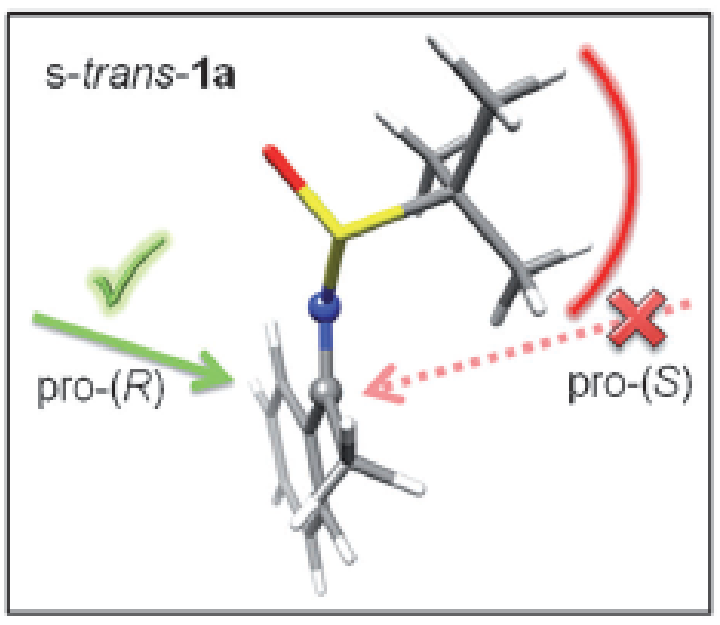

Concerning the reaction profile, it is composed by three intermediates and two transition states (Chart 2), indicating clearly that the process is not concerted but it occurred in two steps: initially an interaction between the ruthenium complex with the imine nitrogen takes place favoring the transfer of the hydride from the metal to the carbon atom of the imine. In a second step the hydrogen transfer occurs between the nitrogen atoms giving the final protected amine (Chart 3). ${ }^{8 b}$ 


\section{Chart 2}

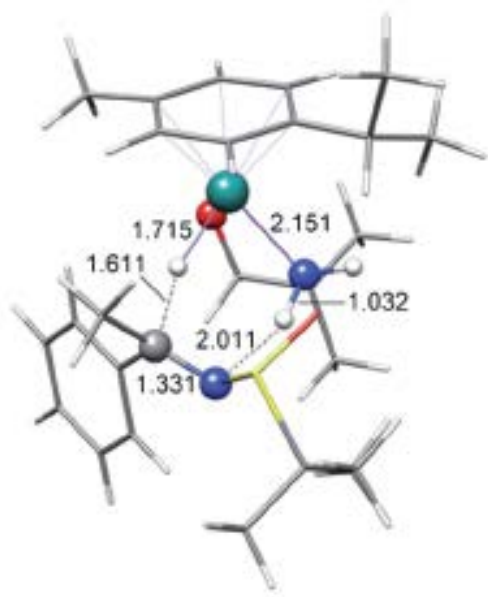

TS-I $\mathbf{I}_{A}$

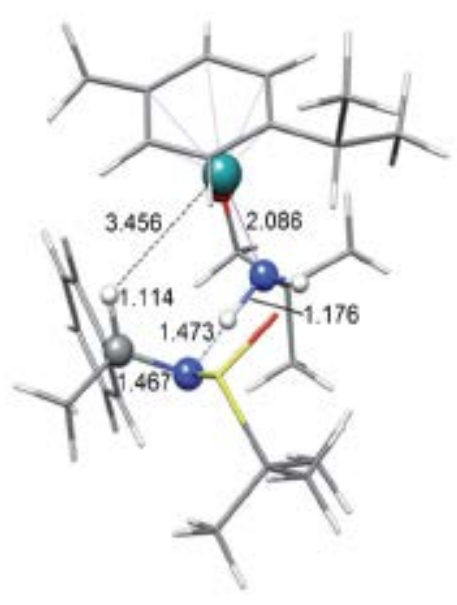

TS-I $\mathbf{I}_{\mathbf{B}}$

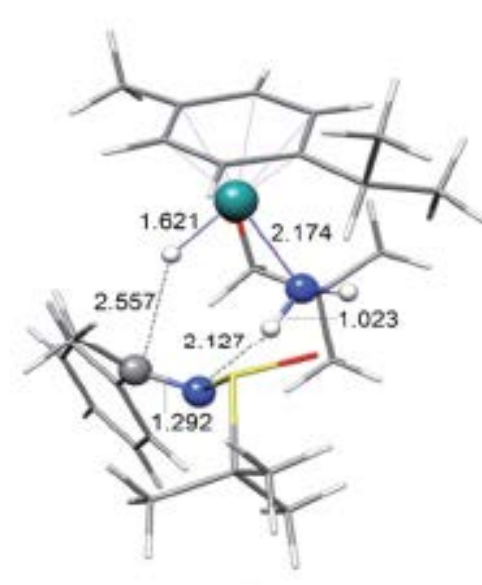

I

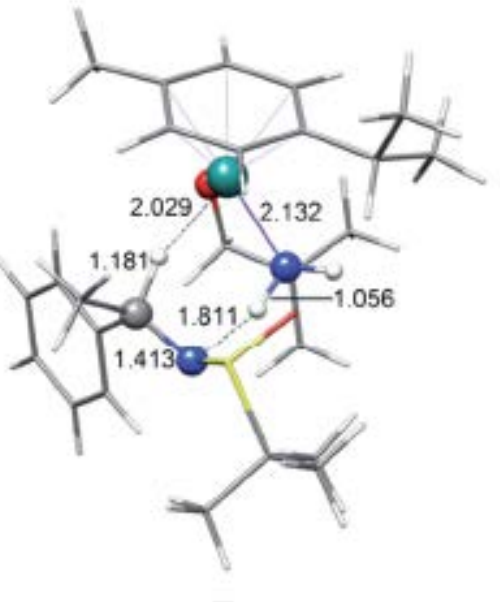

II

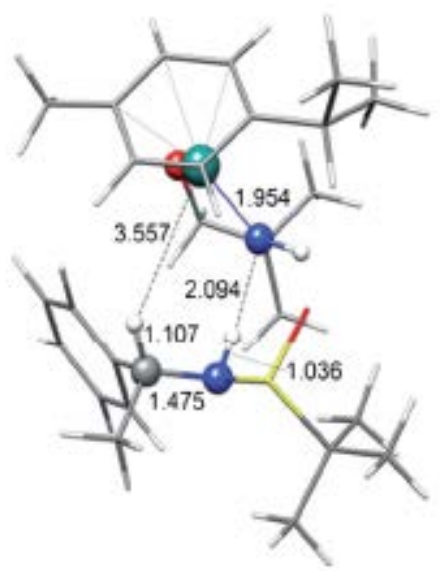

III 


\section{Chart 3}

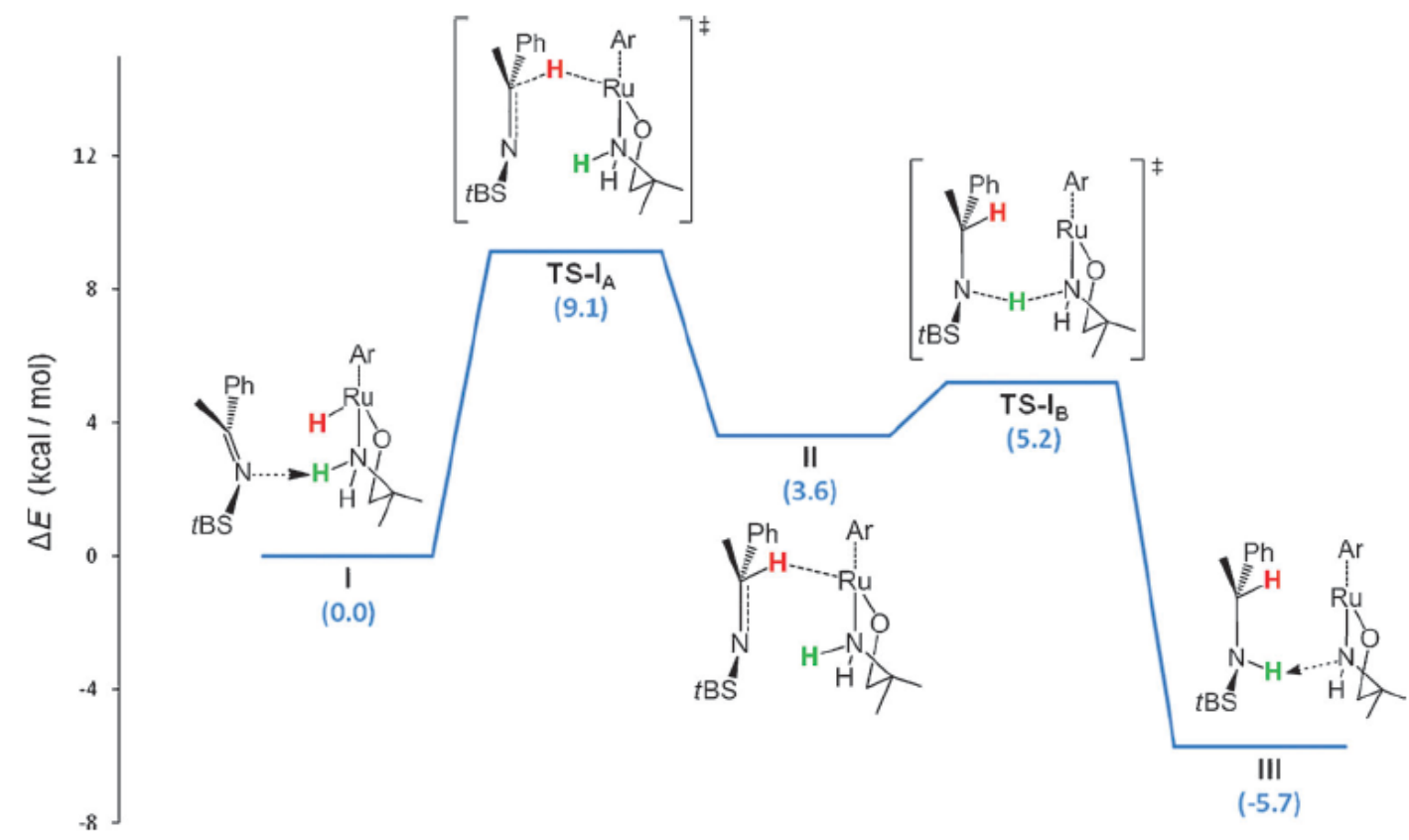

The obtained diastereoselectivity in the first step of the reaction (the hydrogen transfer) can be explained considering the energy of the different possible transition states of the process: after considering both topicities, we found that the transition state TS-Ia was the most stable one, so explaining the diastereoselectivity observed in the hydrogen transfer to the imine (Chart 4). ${ }^{8 \mathrm{~b}}$

\section{Chart 4}

Reduction of the pro- $(R)$ face of the s-trans imine 1a:

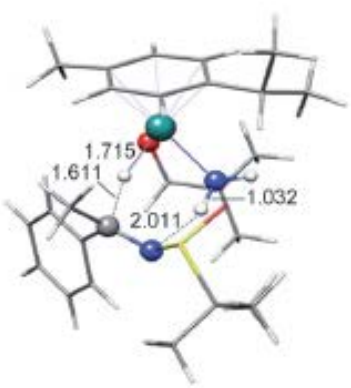

TS-IA $(9.1)$

$\mathrm{Ca},(R)-\mathrm{Ru}$

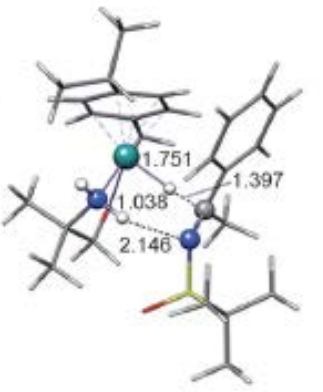

TS- $\mathbf{H}_{\mathbf{A}}(15.1)$

$\mathrm{Ca},(S) \cdot \mathrm{Ru}$

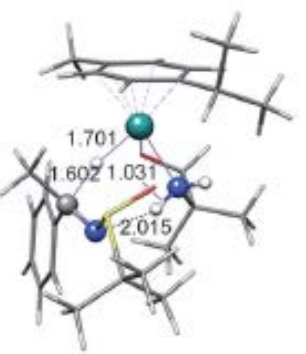

TS- $\mathbf{I H}_{\mathbf{A}}(11.8)$

$\mathrm{Cb},(R) \cdot \mathrm{Ru}$

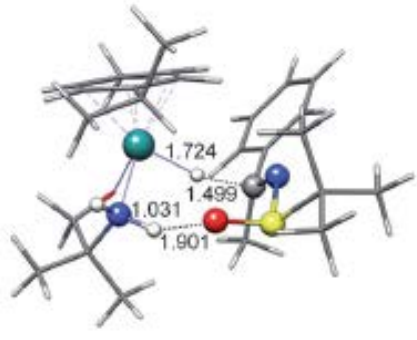

TS-IV A $(12,7)$

$\mathrm{Cb},(S) \cdot \mathrm{Ru}$

Reduction of the pro-(S) face of the s-cis imine 1a:
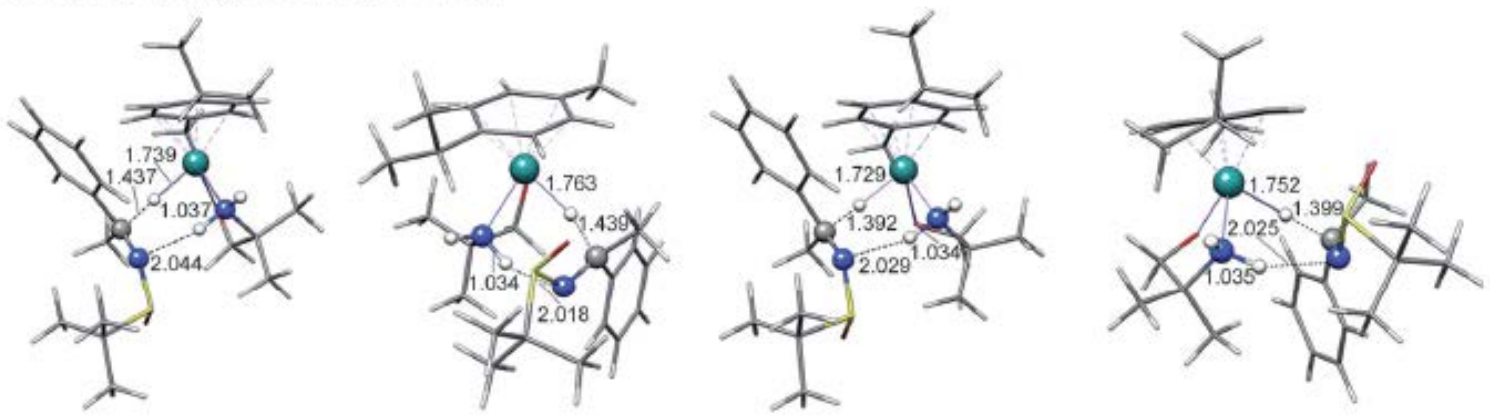

$$
\begin{gathered}
\text { TS-V } \\
\text { Ca }_{\mathbf{A}}(R)-\mathrm{Ru}
\end{gathered}
$$$$
\begin{gathered}
\mathrm{TS}-\mathrm{VI}_{A}(12.3) \\
\mathrm{Ca}_{+}(S)-\mathrm{Ru}
\end{gathered}
$$ 
The above mentioned hydrogen transfer was applied to the preparation of chiral $\gamma-, \delta$-, and $\varepsilon^{-}$ lactams. For that purpose both series of enantiomerically pure chiral iminoesters necessary for carrying out the reduction were prepared from the corresponding ketoesters as it is shown in Scheme $6 .^{9}$

\section{Scheme 6}<smiles>[R]C(=O)CCCC(=O)OCC</smiles><smiles>CCOC(=O)CC/C(=N/S(=O)C(C)(C)C)c1ccccc1</smiles>

$84 \%$ (ent: 84\%)<smiles>CCOC(=O)CCCC(=NS(=O)C(C)(C)C)c1ccc2ccccc2c1</smiles>

$85 \%$

(ent: $84 \%)$<smiles>CCOC(=O)CC/C(=N/S(=O)C(C)(C)C)C1CCCC1</smiles>

$68 \%$

(ent: $70 \%)$<smiles>CCOC(=O)CCC/C(=N\S(=O)C(C)(C)C)c1cccs1</smiles>

$59 \%$

(ent: $58 \%)$<smiles>CCOC(=O)CC/C(=N/S(=O)C(C)(C)C)C(C)C</smiles>

$75 \%$

(ent: $75 \%)$

In a second process, the hydrogen transfer took place very selectively giving, after the final deprotection under acidic conditions, the expected lactams resulting from an spontaneous intramolecular cyclization under the assayed reaction conditions (Scheme 7). ${ }^{9}$ 


\section{Scheme 7}<smiles>[R]C(C)=NS(=O)C(C)(C)C</smiles>

1. $\left[\mathrm{RuCl}_{2}(p \text {-cymene })\right]_{2}(2.5 \%)$

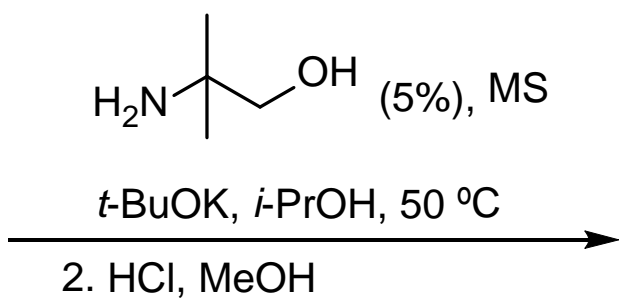<smiles>[R]CCCC(N)=O</smiles>

[12 examples]<smiles>NC(=O)CCCC1CCCCC1</smiles>

93\% (96\% ee) [ent: 93\% (95\% ee)]<smiles>NC(=O)CCCC1CCCC1</smiles>

$$
90 \%(90 \% \text { ee })
$$
[ent: 91\% (90\% ee)]

70-96\%<smiles>O=C1CCC[C@H](c2ccc3ccccc3c2)N1</smiles>

$94 \%(98 \%$ ee $)$ [ent: $93 \%(97 \%$ ee $)$ ]<smiles>O=C1CCC[C@H](c2cccs2)N1</smiles>

$92 \%(98 \%$ ee $)$ [ent: $90 \%(98 \%$ ee $)$ ]
(90->99\% ee)<smiles>CC(C)CCCC(N)=O</smiles>

$89 \%(95 \%$ ee $)$ [ent: $90 \%(94 \%$ ee $)$ ]<smiles>O=C1CCCC[C](c2ccccc2)N1</smiles>

$70 \%(98 \%$ ee $)$ [ent: $72 \%(98 \%$ ee $)$ ]

Another application of the asymmetric hydrogen transfer is the formation of protected saturated nitrogen-containing heterocycles. In This case the necessary chiral $\omega$-chlorinated imines were easily prepared from the corresponding chlorinated ketones, except for the $\beta$-chloro derivative that, probably through the corresponding titanium enolate, decomposes during the reaction (Scheme 8). ${ }^{10}$ 
Scheme 8

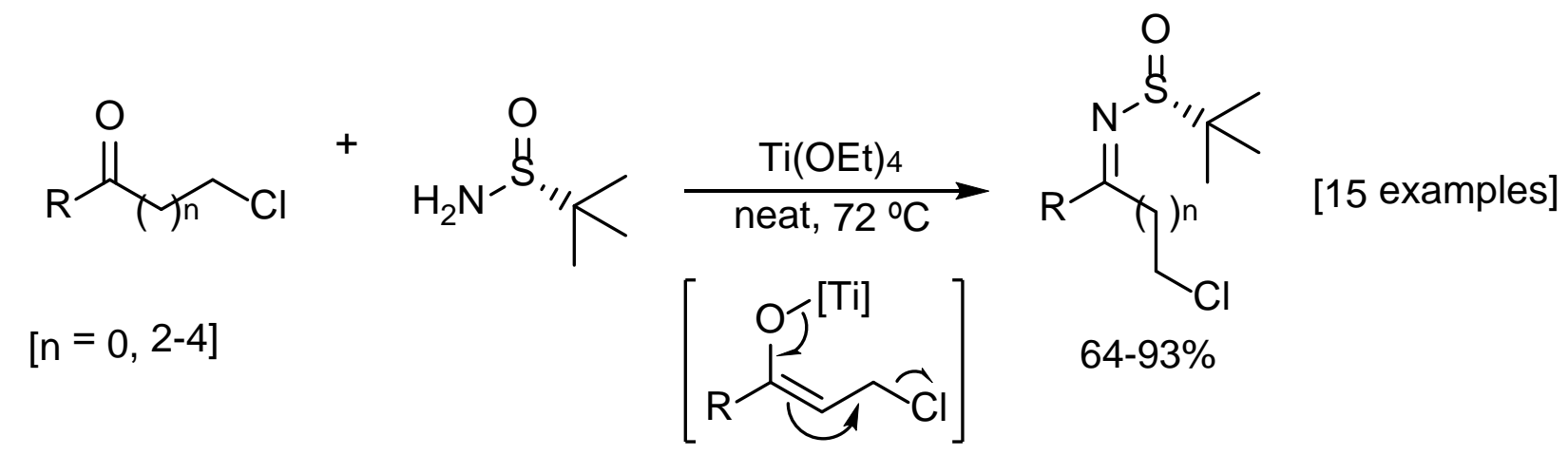<smiles>CC(C)(C)[S@](=O)/N=C(\CCl)c1ccccc1</smiles>

$78 \%$<smiles>CC(C)(C)[S@](=O)/N=C(\CCCCl)c1ccc2ccccc2c1</smiles>

$84 \%$<smiles>CC(C)(C)[S@](=O)/N=C(\CCCCl)c1ccccc1</smiles>

$86 \%$<smiles>CC(C)(C)[S@](=O)/N=C(\CCCCCCl)c1ccccc1</smiles>

$87 \%$<smiles>CC(C)(C)[S@](=O)/N=C(\CCCCCl)c1ccccc1</smiles>

$88 \%$<smiles>Cc1ccc(/C(CCCCl)=N/[S@](=O)C(C)(C)C)cc1</smiles>

$92 \%$

The former chlorinated chiral imines were subjected to the hydrogen transfer giving the expected protected heterocycles with good yields and high diastereoselectivity. For the three and five membered products, the basic conditions needed for the reduction are sufficient for promoting the cyclization (Scheme 9 ). ${ }^{10}$ 
Scheme 9<smiles>[R]C(=NS(=O)C(C)(C)C)[Te]Cl</smiles>

[n $=1,3]$<smiles>CC(C)(C)[S@](=O)N1CC1c1ccccc1</smiles>

$92 \%$

$(99: 1 d r)$<smiles>CC(C)(C)[S@](=O)N1CCC[C@H]1c1ccccc1</smiles>

$84 \%$

$(99: 1 d r)$

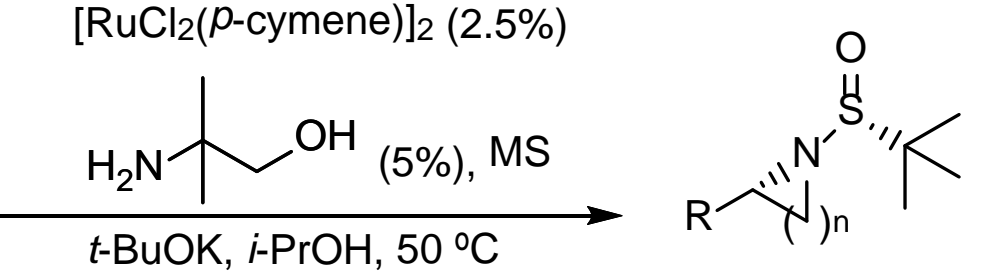

[11 examples]

(96:4->99:1 dr)<smiles>CC(C)(C)[S@](=O)N1CC1c1ccc(Cl)cc1</smiles>

$86 \%$

$(98: 2 d \eta)$<smiles>Cc1ccc([C@@H]2CCCN2S(=O)C(C)(C)C)cc1</smiles>

90\% (99:1 dr) [ent: 91\% (>99:1 dr)]<smiles>CC(C)(C)[C@@H]1CN1S(=O)C(C)(C)C</smiles>

$81 \%$

$(96: 4 d \eta)$<smiles>CC(C)(C)[S@](=O)N1CCC[C@H]1c1cccs1</smiles>

$86 \%$

$(98: 2 d \eta)$

However, in the case of six and seven heterocyclic products a second step using KHMDS as a second base was necessary in order to get the expected cyclization. In addition, to achieve the seven membered heterocycles it was necessary to start from the corresponding brominated materials, because no cyclization was observed with the corresponding chlorinated imines (Scheme 10). ${ }^{10}$ 


\section{Scheme 10}

1. $\left[\mathrm{RuCl}_{2}(p \text {-cymene })\right]_{2}(2.5 \%)$<smiles>[R]C([14CH2]Cl)=NS(=O)C(C)(C)C</smiles>

$[\mathrm{n}=3,4]$<smiles>CC(C)(C)S(=O)N1CCCCC1c1ccccc1</smiles>

$91 \%$

$(99: 1 d \eta$<smiles>Cc1cccc([C@@H]2CCCCN2S(=O)C(C)(C)C)c1</smiles>

$89 \%$
(5\%), MS

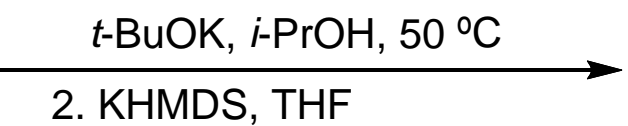<smiles>[R]C1CCN1S(=O)C(C)(C)C</smiles>

$70-91 \%$<smiles>CC(C)(C)S(=O)N1CCCCC[C@H]1c1ccccc1</smiles>

$72 \%$ $(>99: 1 d \eta)$<smiles>COc1cccc(C2CCCCCN2S(=O)C(C)(C)C)c1</smiles>

$(>99: 1 d \eta)$

[* : from the brominated SM]

\section{Addition of zincates to chiral $\mathrm{N}$-tert-butylsulfonyl imines}

In the last few years we have been interested in the enantioselective addition of dialkylzinc reagents to carbonyl compounds, ${ }^{11}$ this methodology being especially useful when the electrophile is a ketone because in this case a tertiary stereocentre is created. ${ }^{12}$

Recently, we studied the addition of dialkylzinc to chiral sulfinyl imines. Surprisingly working at room temperature no reaction was observed. However when an in situ magnesium zincate was used, the reaction took place at $-78{ }^{\circ} \mathrm{C}$ with quantitative yields and excellent enantioselectivities. One important remark is that in this process the methyl group, either coming from dimethylzinc or from the methyl Grignard reagent, was never transferred to the imine. In fact, using the methyl substituent in both reagents, both a very poor yield and diastereoselectivity were observed (Scheme 11). ${ }^{13}$ 
Scheme 11

no reaction

$\frac{\mathrm{Et}_{2} \mathrm{Zn}, \mathrm{MeMgBr}}{\mathrm{THF},-78^{\circ} \mathrm{C}, 1 \mathrm{~h}}$<smiles>CC(C)(C)[S@](=O)/N=C/c1ccccc1</smiles><smiles>CC(C)(C)Br</smiles><smiles>CC[C@H](NS(=O)C(C)(C)C)c1ccccc1</smiles>

$85 \%$

$(98: 2 d \eta$<smiles>CC(C)(C)[S@](=O)/N=C/c1ccccc1</smiles>

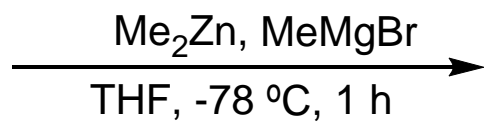<smiles>CC(NS(=O)C(C)(C)C)c1ccccc1</smiles>

The reaction shown in Scheme 11 is very versatile and when connected to the in situ final deprotection under acidic conditions yielded the corresponding chiral primary amines bearing a secondary stereocenter (Scheme 12). ${ }^{13}$ 
Scheme 12

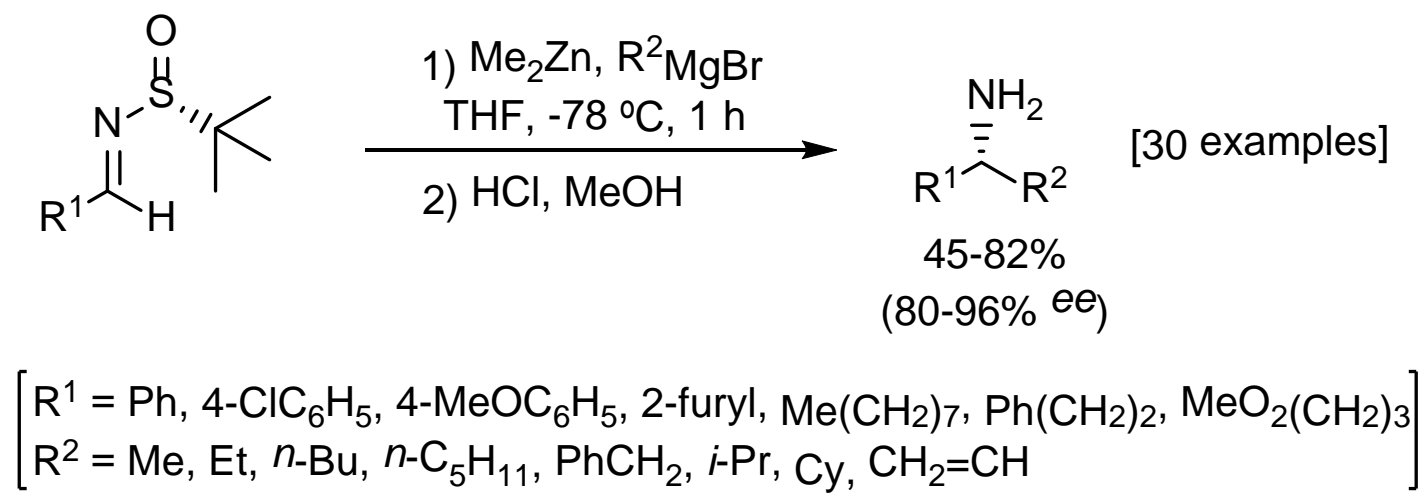<smiles>CC[C@H](N)c1ccccc1</smiles>

$77 \%$

(96\% ee)<smiles>CCCC[C@H](N)c1ccccc1</smiles>

$72 \%$ (92\% ee)<smiles>CCCCC[C@H](N)c1ccccc1</smiles>

$70 \%$

(92\% ee)<smiles>N[C@@H](Cc1ccccc1)c1ccccc1</smiles>

$80 \%$

(80\% ee)<smiles>CC(C)[C@H](N)c1ccccc1</smiles>

$72 \%$ (88\% ee)<smiles>N[C@@H](c1ccccc1)C1CCCCC1</smiles>

$45 \%$

$(86 \%$ ee)<smiles>C=C[C@H](N)c1ccccc1</smiles>

$75 \%$ (90\% ee)

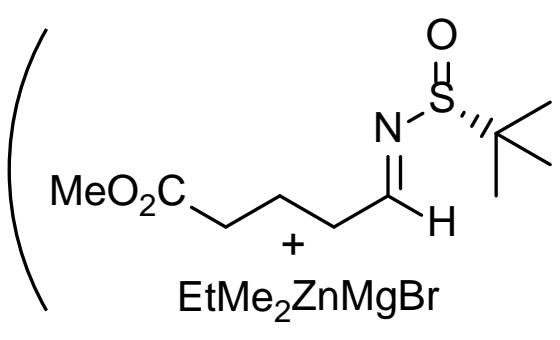<smiles>CC[C@@H]1CCCC(=O)N1</smiles>

The application of this methodology to imines derived from $\alpha$-keto esters can be used to generate tertiary $\alpha$-substituted amino acid derivatives. Thus, starting from the imine of a $\alpha$ oxophenyl acetic ester the expected chiral $\alpha$-amino esters are obtained. It is interesting to note that the observed stereochemistry is the opposite compared to that resulting from the reaction using a Grignard reagent instead of the corresponding zincate. This behavior can be easily explained considering that in the case of the Grignard reaction a chair-like transition state is involved in the process (Scheme 13). ${ }^{13}$ 


\section{Scheme 13}<smiles>[R]OC(=O)/C(=N/S(=O)C(C)C)C(=O)O</smiles>

1) $\mathrm{Me}_{2} \mathrm{Zn}, \mathrm{EtMgBr}$

2) $\mathrm{HCl}, \mathrm{MeOH}$<smiles>[R]OC(=O)[C@](N)(CC)c1ccccc1</smiles>

$82-87 \%$

$(60-82 \%$ ee)<smiles>[R]OC(=NS(=O)C(C)(C)C)c1ccccc1</smiles>

1) $\mathrm{EtMgBr}$

THF, $-78^{\circ} \mathrm{C}, 1 \mathrm{~h}$

2) $\mathrm{HCl}, \mathrm{MeOH}$<smiles>[R]OC(=O)[C@](N)(CC)c1ccccc1</smiles>

$78-79 \%$

(58-70\% ee)

[R $=$ Et, $i$-Pr]

Since the methyl group is not transferable, it would be possible to use a substoichiometric amount of the zinc reagent. That was the case, so using only $15 \%$ of dimethyl zinc similar results were obtained compared to the reaction with stoichiometric amounts of the reagent (see above). In order of this reaction to occur it was necessary to perform an inverse addition of the reagents. For the alternative combination, that is the generation of the zincate with methylmagnesium bromide, at least a $50 \%$ of the corresponding zinc reagent is necessary (Scheme 14$).{ }^{14}$

\section{Scheme 14}<smiles>CC(C)(C)S(=O)/N=C\c1ccccc1</smiles>

1) $\mathrm{RMgBr}, \mathrm{Me}_{2} \mathrm{Zn}(15 \%)$

$$
\text { THF, }-78{ }^{\circ} \mathrm{C}, 1 \mathrm{~h}
$$

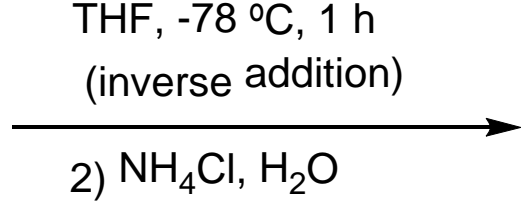<smiles>[R]C(NS(=O)C(C)(C)C)c1ccccc1</smiles>

[4 examples]

$\left[\mathrm{R}=\mathrm{Et}, n-\mathrm{C}_{5} \mathrm{H}_{11}, i-\mathrm{Pr}, \mathrm{CH}_{2}=\mathrm{CH}\right]$<smiles>CC(C)(C)[S@](=O)/N=C/c1ccccc1</smiles>

$[\mathrm{R}=\mathrm{Et}, i-\mathrm{Pr}]$
1) $\mathrm{MeMgBr}, \mathrm{R}_{2} \mathrm{Zn}(50 \%)$

$$
\text { THF, }-78^{\circ} \mathrm{C}, 1 \mathrm{~h}
$$

(inverse addition)

2) $\mathrm{NH}_{4} \mathrm{Cl}, \mathrm{H}_{2} \mathrm{O}$<smiles>[R]C(NS(=O)C(C)(C)C)c1ccccc1</smiles>

[2 examples]
84-90\%

$(94: 6-97: 3 d \eta)$ 
The above mentioned methodology has been successfully applied to the preparation of $\mathrm{N}$ protected chiral $\alpha$-amino acids. Thus, adding the zincate derived from vinylmagnesium bromide following by desulfinylation and final protection of the amine functionality as the corresponding benzoyl derivative afforded the expected chiral allylamine with good yields and enantioselectivities. The oxidative cleavage of the carbon-carbon double bond under standard conditions gave the expected $N$-protected amino acids (Scheme 15). ${ }^{15}$

\section{Scheme 15}

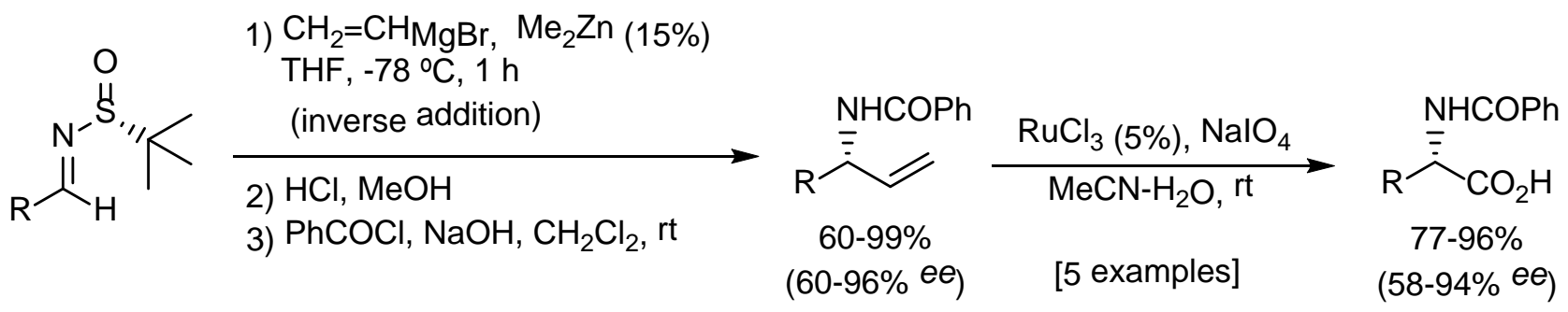<smiles>O=C(N[C@@H](C(=O)O)c1ccccc1)c1ccccc1</smiles><smiles>O=C(N[C@@H](C(=O)O)c1ccc(Cl)cc1)c1ccccc1</smiles><smiles>O=C(N[C@@H](C(=O)O)c1ccc(Cl)cc1)c1ccccc1</smiles><smiles>O=C(N[C@@H](CCc1ccccc1)C(=O)O)c1ccccc1</smiles><smiles>CCCCCCCC[C@H](N)C(=O)O</smiles>

The corresponding ent-amino acids were accessible when the same process was applied to the sunfinylimine derived from furfural. In this case the oxidation step performed under the same reaction conditions gave the enantiomeric products compared to those shown in Scheme 15. It is remarkable that starting from imines with the same configuration at the sulphur atom, both series of amino acids are available (Scheme 16). ${ }^{15}$ 


\section{Scheme 16}

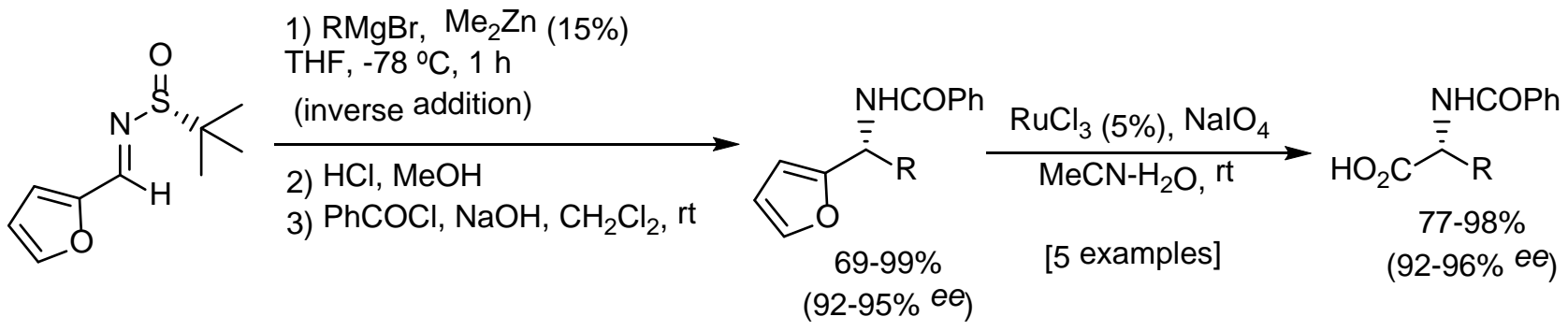<smiles>CC[C@H](NC(=O)O)C(=O)c1ccccc1</smiles><smiles>CC(C)C[C@H](NC(=O)Oc1ccccc1)C(=O)O</smiles>

$75 \%$ $(92 \%$ ee)

\section{8\%} $\left(96 \%{ }^{e e}\right)$<smiles>O=C(N[C@@H](Cc1ccccc1)C(=O)O)c1ccccc1</smiles>

$90 \%$ $(92 \%$ ee)<smiles>CCCCCC[C@H](N)C(=O)O</smiles>

$77 \%$ $(92 \%$ ee)<smiles>CC(C)[C@H](NC(=O)O)C(=O)O</smiles>

$88 \%$

$(92 \%$ ee)

$\mathrm{N}$-Protected $\alpha$-substituted $\alpha$-amino acids of the type shown in Scheme 13 were prepared using the procedure employing a substoichiometric amount of dimethylzinc as it is depicted in Scheme $17 .{ }^{15}$

\section{Scheme 17}<smiles>CCOC(=O)/C(=N/S(=O)C(C)(C)C)c1ccccc1</smiles>

1) $\mathrm{RMgBr}, \mathrm{Me}_{2} \mathrm{Zn}(15 \%)$

THF, $-78^{\circ} \mathrm{C}, 1 \mathrm{~h}$

(inverse addition)

2) $\mathrm{HCl}, \mathrm{MeOH}$

3) $\mathrm{PhCOCl}, \mathrm{NaOH}, \mathrm{CH}_{2} \mathrm{Cl}_{2}$, rt<smiles>[R][C@](N)(C(=O)OCC)c1ccccc1</smiles>

[3 examples]

$74-96 \%$

$(62-92 \%$ ee)<smiles>CCOC(=O)C(CC)(c1ccccc1)c1ccccc1</smiles>

96\%

$(92 \%$ ee)<smiles>CCOC(=O)C(Cc1ccccc1)(c1ccccc1)c1ccccc1</smiles>

$74 \%$

$(80 \%$ ee)<smiles>CCOC(=O)[C@@](NC(=O)c1ccccc1)(c1ccccc1)C(C)C</smiles>

$84 \%$ $(62 \%$ ee $)$ 
Finally, $\beta$-amino acid derivatives were prepared by the same procedure shown in Scheme 15 but using allylmagnesium bromide instead of the vinyl Grignard. After the final oxidation of the homoallyl chiral $N$-benzyl amines were isolated. It is worthy to note that the new stereocenter has the opposite configuration that the 'normal' one resulting from the addition of other Grignard reagent to the chiral imine: this behavior can be easily explained considering that the allyl moiety allows the reaction to take place through a chair-like transition state locating the bulky aryl group in a pseudoequatorial position (Scheme 18). ${ }^{15}$

\section{Scheme 18}
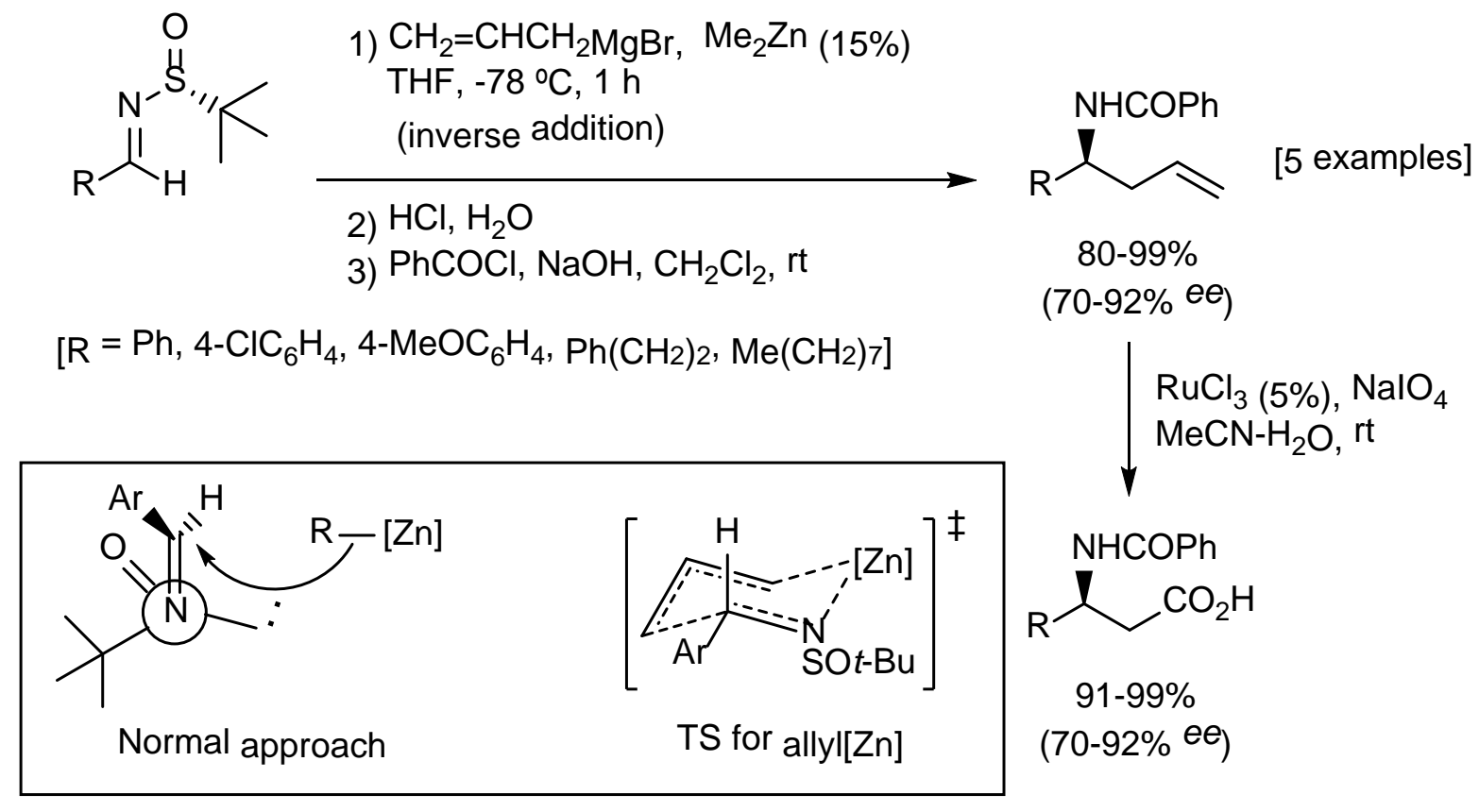

$(70-92 \%$ ee $)$

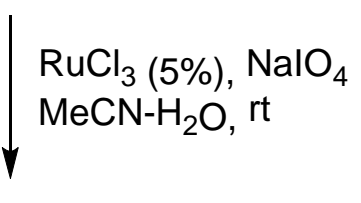<smiles></smiles><smiles>CC(C)(C)OC(=O)N[C@@H](CC(=O)O)c1ccccc1</smiles><smiles>O=C(O)C[C@H](NC(=O)O)c1ccc(Cl)cc1</smiles><smiles>COc1ccc([C@H](CC(=O)O)NC(=O)c2ccccc2)cc1</smiles><smiles>O=C(O)C[C@H](CCc1ccccc1)NC(=O)c1ccccc1</smiles>

\section{Indium-promoted allylation of $\mathrm{N}$-(tert-butyl)sulfinyl imines}

The allylation of imines using an organometallic reagent has been far less studied than the corresponding addition to carbonyl compounds. ${ }^{16}$ The asymmetric version of this process would allow the preparation of chiral homoallylamines, susceptible of being transformed in other useful functionalities. ${ }^{17}$ Some years ago ${ }^{18}$ we discovered that indium metal is able to promote the allylation of chiral $\mathrm{N}$-sulfinyl imines with different allyl bromides under mild reaction conditions, so the corresponding protected homoallylamines could be prepared with high yields and diastereoselectivities. ${ }^{19}$ One interested version of this reaction implies the use of a multicomponent process $^{20}$ which allows the in situ generation of the imine in the presence of the allylation reagent. In any case a chair-like transition state has been postulated to explain the obtained results (Scheme 19). ${ }^{21}$ 


\section{Scheme 19}<smiles>[R]C(=C)CC([R])NS(=O)C(C)(C)N[C@@H]([R])CC(=O)O</smiles>

$79-94 \%$

(88:12-96:4 dr)

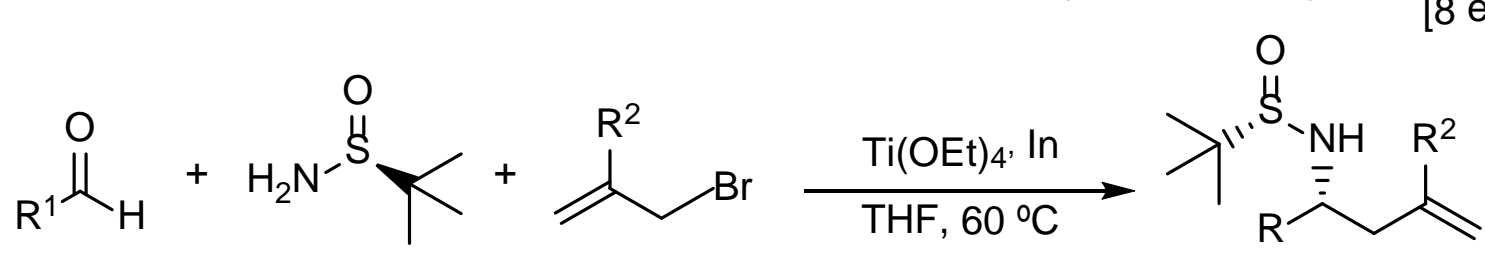

[8 examples]

$72-92 \%$

$\left[\begin{array}{l}\mathrm{R}^{1}=i-\mathrm{Pr}, \mathrm{Me}\left(\mathrm{CH}_{2}\right) 7, \mathrm{Ph}, \mathrm{PhCH}_{2}, \mathrm{Ph}\left(\mathrm{CH}_{2}\right)_{2},(E)-\mathrm{PhCH}=\mathrm{CH} \\ \mathrm{R}^{2}=\mathrm{H}, \mathrm{Me}\end{array}\right]$

$(89: 11-98: 2 d r)$<smiles>C=CC(C)(C)[C@H](CCc1ccccc1)NS(=O)C(C)(C)C</smiles>

$89 \%$<smiles>CC(C)(C)S(=O)N[C@H](CCc1ccccc1)[C@H]1C=CCCC1</smiles>

$87 \%(96: 4 d \eta$

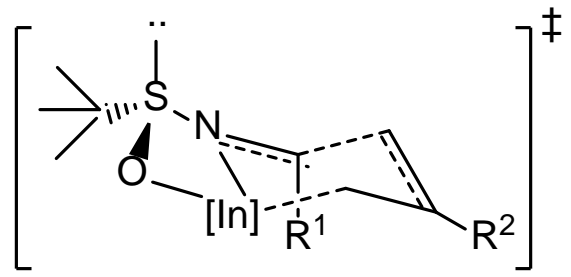

The protected homoallylamines shown in the Scheme 19 are interesting materials for the preparation of several piperidine derived alkaloids in a chiral form. The cross metathesis with methyl vinyl ketone under ruthenium catalysis afforded a new enone, which after a tandem catalytic hydrogenation, deprotection and final reduction gave after acidic work-up the expected alkaloids with a cis configuration, after a spontaneous intramolecular cyclization, previous to the reduction. In the case of the benzaldehyde imine, a final oxidation of the phenyl group under standard conditions gave 6-methylpipecolic acid with modest yield but total enantioselectivity (Scheme $20)^{22}$ 
Scheme 20
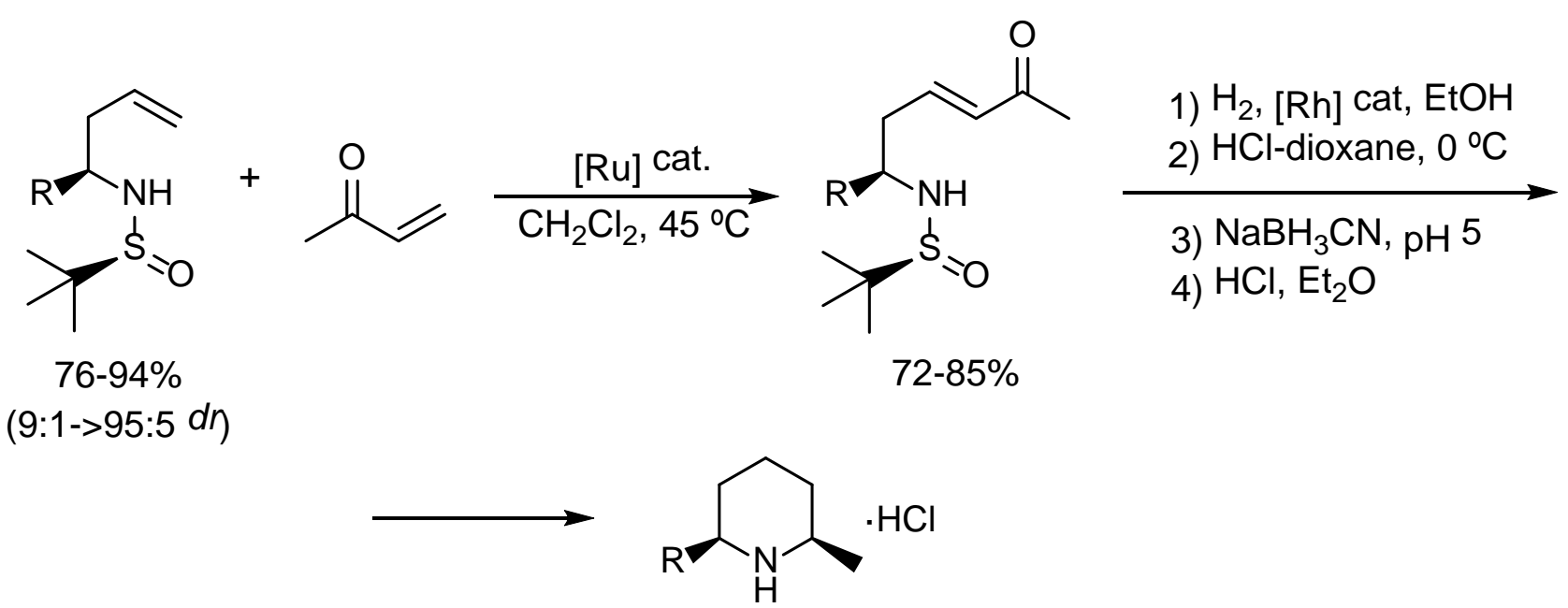

$\mathrm{R}=n$-Pr: (+)-dihydropinidine (85\%)

$\mathrm{R}=\mathrm{Me}\left(\mathrm{CH}_{2}\right) 8^{:}(+)$-isosolenopsine $(93 \%)$

$\mathrm{R}=\mathrm{Me}\left(\mathrm{CH}_{2}\right) 10^{\circ}(+)$-isosolenopsine $\mathrm{B}(95 \%)$

$\mathrm{R}=\mathrm{Ph}(94 \%) \underset{[\mathrm{O}]}{\longrightarrow} \begin{aligned} & 6 \text {-methylpipecolic } \\ & \text { acid }(41 \%)\end{aligned}$

The corresponding trans compounds can be selectively produced varying the reduction conditions. Scheme 21 shows an example of this methodology leading to the the alkaloid $\left(^{+}\right)-$ solenopsine with high yield and diastereoselectivity (Scheme 21). ${ }^{23}$

Scheme 21<smiles>CC(=O)/C=C\C[C@H](CC(C)C)NS(=O)C(C)(C)C</smiles>

1) $\mathrm{H}_{2}$, [Rh] cat., $\mathrm{EtOH}$

2) $\mathrm{HCl}$-dioxane, $0^{\circ} \mathrm{C}$<smiles>CCC1CCCC(C)=N1</smiles><smiles>CC[C@H]1CCC[C@@H](C)N1</smiles>

(+)-solenopsine 83\% (>98:2 $d r$ ) 
Another application of the $N$-sulfinyl homoallyl amines (Scheme 19) involves the oxidation of the carbon-carbon double bond to give the corresponding epoxides: in this non-diastereoselective process a concomitant oxidation of the sulfur atom takes also place. The resulting epoxides mixture was kinetically resolved using Jacobsen methodology ${ }^{24}$ so the easily separable mixtures of enantiomerically pure epoxides and diols were obtained. Actually the diols were transformed into the same epoxides by well-known procedures. The obtained epoxides are successfully cyclized to the corresponding chiral protected substituted azetidines or pyrrolidines by using potassium carbonate alone or in the presence on potassium iodide, respectively (Scheme 22). ${ }^{25}$

\section{Scheme 22}

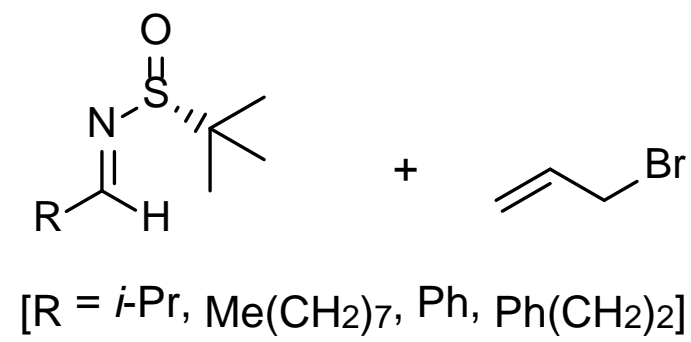

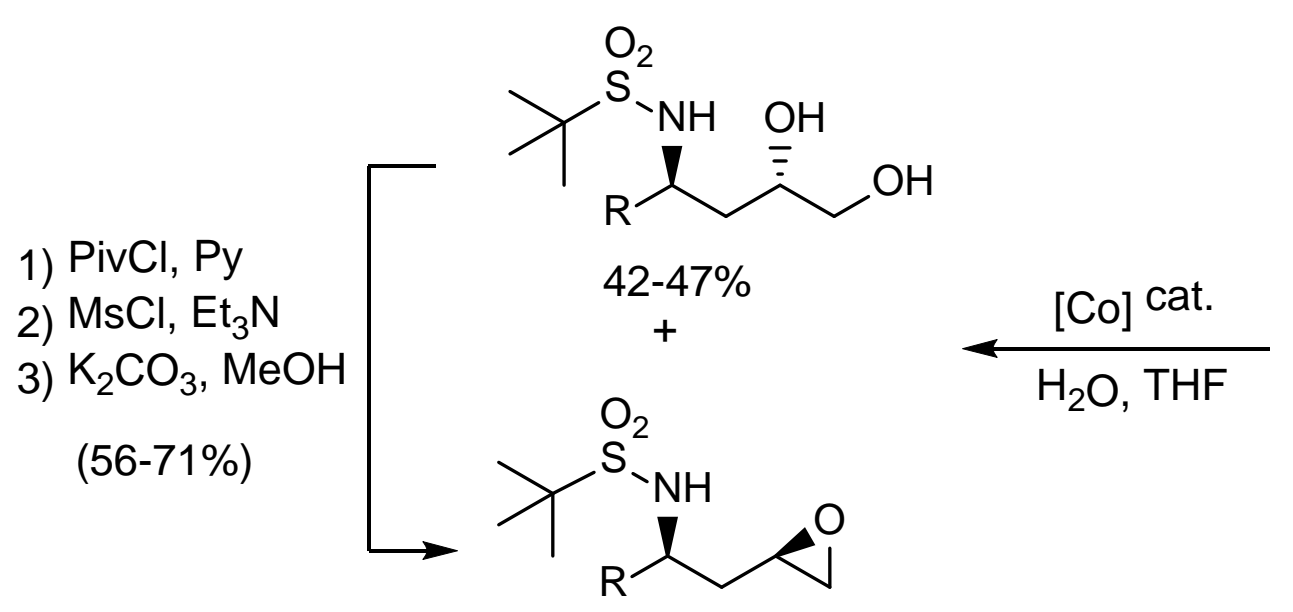

$\left[\mathrm{R}=\mathrm{i}-\mathrm{Pr}, \mathrm{Me}\left(\mathrm{CH}_{2}\right) 7, \mathrm{Ph}, \mathrm{Ph}\left(\mathrm{CH}_{2}\right)_{2}\right.$

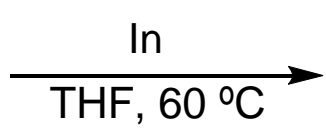<smiles>[R]C(CC=C)NS(=O)C(C)(C)C</smiles>

$75-94 \%$ 


\section{Scheme 23}<smiles>[R]/C=N\[S@](=O)C(C)(C)C</smiles><smiles>C=C(CBr)C(=O)OCC</smiles>

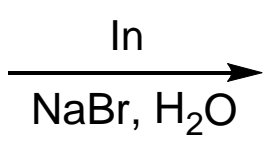

[8 examples]

$\left[\mathrm{R}=i-\mathrm{Pr}, \mathrm{Me}\left(\mathrm{CH}_{2}\right){ }_{7}, \mathrm{Ph}, \mathrm{Ph}\left(\mathrm{CH}_{2}\right)_{2}\right]$

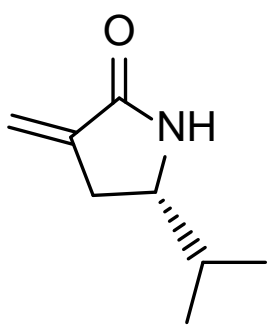

91\%

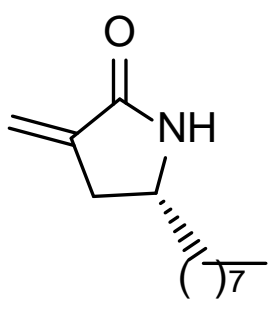

$92 \%$<smiles>C=C1C[C@H](c2ccccc2)NC1=O</smiles>

$93 \%$<smiles>[R][C@H](CC(=C)C(=O)OCC)NS(=O)C(C)(C)C</smiles>

$73-82 \%$

(86:14-95:5 $d r)$

1) $\mathrm{HCl}$, dioxane $\mathrm{MeOH}, 0^{\circ} \mathrm{C}$ 2) $\mathrm{NaOMe}, \mathrm{MeOH}$ $0^{\circ} \mathrm{C}$

The presence of a bromine atom at the $\delta$-position provoked an intramolecular spontaneous cyclization of the intermediate homoallylamine to yield 2-allyl- $N$-sulfinylpiperidine in an enantiomerically pure form, wich can be easily deprotected to the corresponding secondary amine as its hydrochloride (Scheme 24). ${ }^{27}$ 
Scheme 24

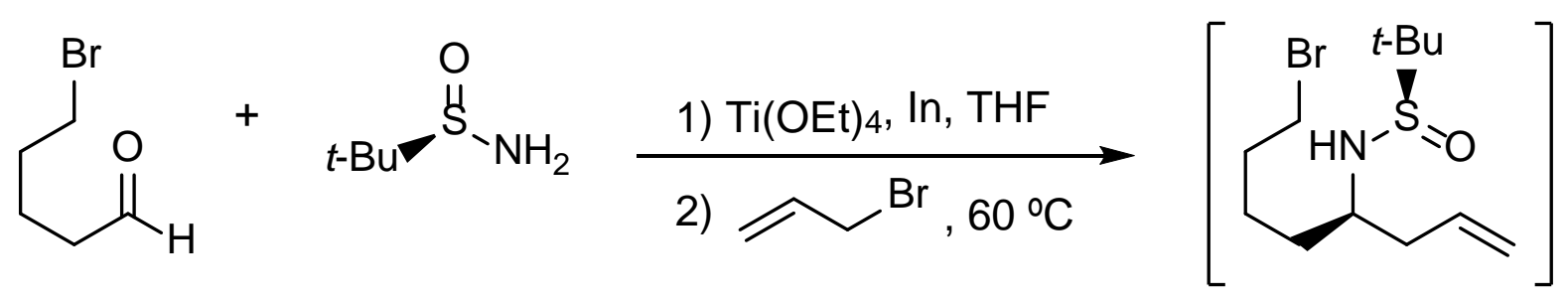

(94:6 $d \eta)$

KHMDS

THF, $0^{\circ} \mathrm{C}$

$\overbrace{\mathrm{H}} \cdot \mathrm{HCl}$

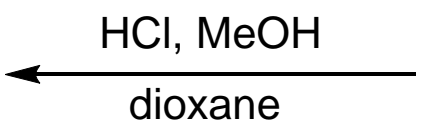

$95 \%$

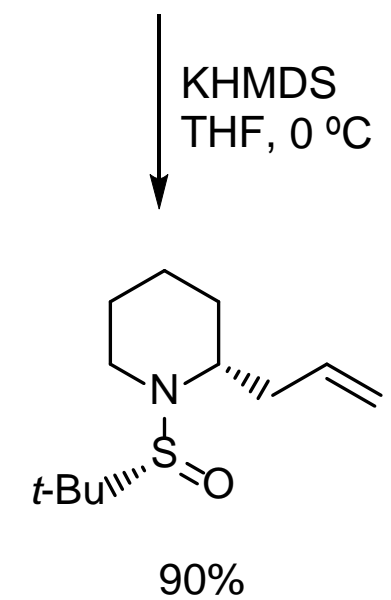

The chiral 2-allylpiperidine shown in Scheme 24 is a valuable precursor to obtain other interesting nitrogen-containing molecules. Thus, its direct hydrogenation afforded (+)-coniine. By acrylation following by ring-clossing metathesis the corresponding bicyclic lactam was obtained, which was easily transformed into a methylated derivative, direct precursor of the alkaloid (-)cermizine C (Scheme 25). ${ }^{27}$ 
Scheme 25

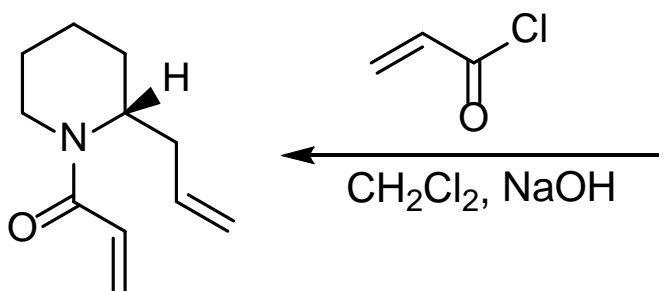

$82 \%$

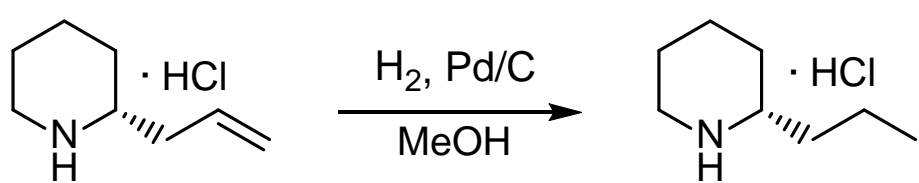

(+)-coniine (78\%)

[Ru]-cat.

$\mathrm{CH}_{2} \mathrm{Cl}_{2}$ reflux<smiles>O=C1C=CC[C@H]2CCCCN12</smiles>

$80 \%$

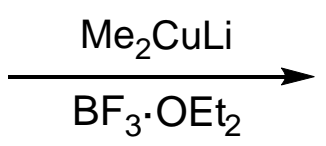

$78 \%$
[<smiles>C[C@H]1C[C@H](C)N2CCCC[C@@H]2C1</smiles>

(-)-cermizine C

The same starting material, after protecting the nitrogen as a Boc derivative was oxidized under Wacker-type conditions to give, after deprotection, the alkaloid (-)-pelliterine. This compound was transformed into 5-epi-(+)-cermizine $\mathrm{C}$ by a tandem condensation with Meldrun acid, catalytic hydrogenation and final methylation under standard conditions (Scheme 26). ${ }^{27}$ 
Scheme 26

$\overbrace{\mathrm{H}}^{\mathrm{HCl}}$
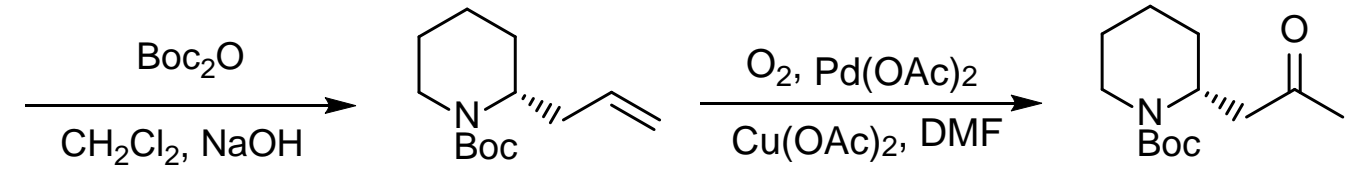

$93 \%$

$70 \%$<smiles>C[C@@H]1CC(=O)N2CCCC[C@H]2C1</smiles>

$96 \%$ $(13: 1 d r)$<smiles>CCO[Po](=O)OCC</smiles><smiles>CC1=C[C@H]2CCCCN2C(=O)C1</smiles>

$67 \%$<smiles></smiles>

(-)-pelliterine (94\%)
1) $\mathrm{MeMgBr}, \mathrm{THF}, 65^{\circ} \mathrm{C}$
2) $\mathrm{NaBH}_{3} \mathrm{CN}, \mathrm{AcOH}$
3) $\mathrm{TFA}, \mathrm{MeOH}$

1) $\mathrm{MeMgBr}, \mathrm{THF}, 65$
2) $\mathrm{NaBH}_{3} \mathrm{CN}, \mathrm{AcOH}$
3) $\mathrm{TFA}, \mathrm{MeOH}$

1) $\mathrm{MeMgBr}, \mathrm{THF}, 65$
2) $\mathrm{NaBH}_{3} \mathrm{CN}, \mathrm{AcOH}$
3) $\mathrm{TFA}, \mathrm{MeOH}$

5-epi-(+)-cermizine C (66\%)

A little bit more sophisticated is the preparation of tetraponerine T3 starting from the same material. After changing the protection at the nitrogen atom, the corresponding Cbz-derivative was submitted to oxidative cleavage to give an aldehyde which was transformed into the corresponding homoallylamine using the same methodology used for the preparation of the starting material in an iterative process. Tandem deprotection of this compound followed by catalytic hydrogenation and reaction with $\gamma$-bromobutanal under basic conditions afforded the expected alkaloid. When the second allylation was performed with the enantiomeric sulfinamide, the epimeric tetraponerine T4 was obtained (Scheme 27). ${ }^{28}$ 
Scheme 27

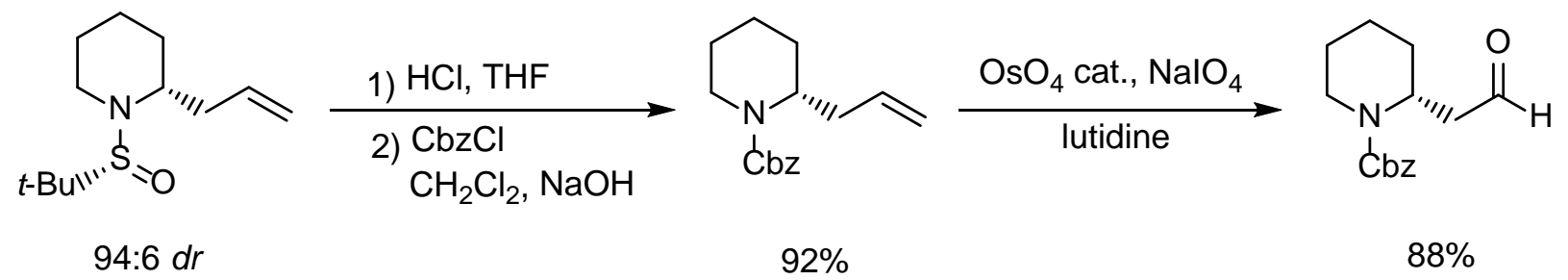<smiles>C=CCC(=O)OCC(=O)O</smiles><smiles>[Y20]C(=O)OCCCCCCC(=O)O</smiles>

tetraponerine T3 (54\%)

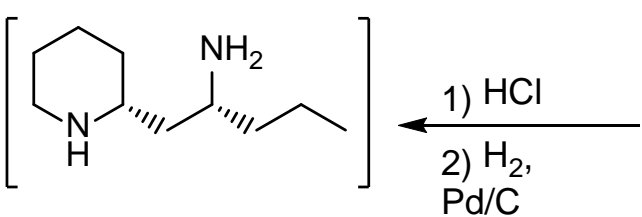

(not isolated)<smiles>C=CC[C@H](C[C@@H]1CCCCN1C(=O)OCc1ccccc1)NS(=O)C(C)(C)C</smiles>

$72 \%$ single isomer

For the preparation of the alkaloid (-)-aphanorphine it was necessary the allylation of the in situ generated imine derived from 4-methoxybenzaldehyde with methallyl bromide. The obtained homoallylamine was then oxidized with concomitant oxidation of the sulphur atom to give an epoxide which was cyclized in the presence of potassium iodide to yield the desired five-membered ring. However the Friedel-Crafts reaction of this alcohol under classical conditions did not take place, so it was necessary to exchange the protecting group at the nitrogen atom by benzoylation and then the electrophilic substitution took place to give the skeleton of the alkaloid, which was accessible by simple selective methylation at the nitrogen and demethylation at the oxygen atom. Starting from the enantiomeric sulfinamide we were able to prepare the enantiomeric $(+)$ aphanorphine using the same methodology (Scheme 28). ${ }^{29}$ 
Scheme 28<smiles>COc1ccc(C=O)cc1</smiles>

1) In, Ti(OEt)4 THF, $1 \mathrm{~h}$

2)<smiles>C=C(C)CBr</smiles>
$60^{\circ} \mathrm{C}$<smiles>C=C(C)C[C@H](Cc1ccc(OC)cc1)NS(=O)C(C)(C)C</smiles>

$92 \%$

$(93: 7 d \eta$

1) $\mathrm{m}_{\mathrm{CPBA}} \mathrm{NaHCO}_{3}$ $\mathrm{CH}_{2} \mathrm{Cl}_{2}, 0^{\circ} \mathrm{C}$

2) $\mathrm{KI}, \mathrm{K}_{2} \mathrm{CO}_{3}$ DMF, $100^{\circ} \mathrm{C}$<smiles>COc1ccc(C[C@@H]2C[C@@H]3C[C@@H]2CC[C@H]3O)cc1</smiles>

$95 \%$

2) $\mathrm{NaOH}, 80{ }^{\circ} \mathrm{C}$

$63 \%$

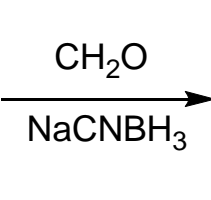

1) $\mathrm{TfOH}, \mathrm{PhOMe}$

2) $\mathrm{PhCOCl}, \mathrm{NaOH}$<smiles>COc1ccc(C[C@@H]2CC3(O)C[C@@H]2CN(S(=O)(=O)OC(C)(C)C)C3)cc1</smiles>

$59 \%$

1:1 mixture
1) $\mathrm{AlCl}_{3}$, $\mathrm{CH}_{2} \mathrm{Cl}_{2}$<smiles>COc1ccc2c(c1)[C@]1(C)CN[C@H](C2)[C@H]1NO</smiles><smiles>COc1ccc2c(c1)[C@]1(C)CC[C@H](C)C[C@H]2C1</smiles>

$95 \%$<smiles>C[C@H]1Cc2ccc(O)cc2[C@@]2(C)CC[C@H]1C2</smiles>

(-)-aphanorphine (42\%)

The chiral $N$-(tert-butyl)sulfinyl imine derived from 3-(2-bromophenyl)propanal was the starting material to prepare (-)-angustureine. This compound was reacted with pentylmagnesium bromide, and after desulfinylation and cyclization under palladium catalysis gave a compound that was transformed into the mentioned alkaloid by $N$-methylation (Scheme 29). ${ }^{30}$ The substitution of the Grignard compound by 2-(3,4-dimehoxyphenyl)ethylmagnesium bromide allowed the synthesis of (-)-cuspareine following the same sequence of reactions. ${ }^{30}$ 
Scheme 29

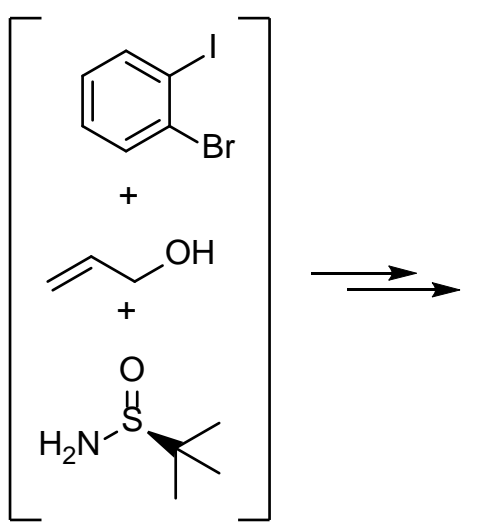

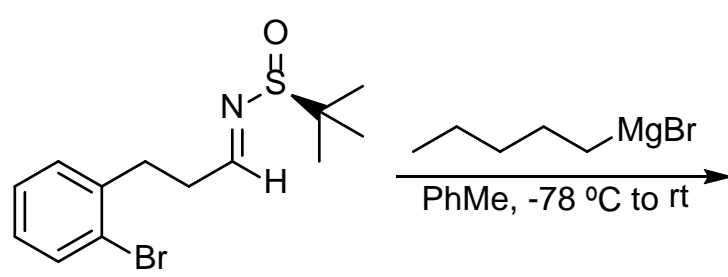<smiles>CCCCC[C@H](CCc1ccccc1Br)NS(=O)C(C)(C)C</smiles><smiles>CCCCC[C@H](C)Nc1ccccc1CC</smiles><smiles>CC(C)COC(=O)C(O)C(C)(C)C</smiles><smiles>CCCCC[C@@H]1CCc2ccccc2N1</smiles>

$81 \%$
$\frac{\mathrm{Pd}(\mathrm{OAc})_{2}(5 \%)}{\mathrm{PPh}_{3}, \mathrm{CsCO}_{3}}$

PhMe reflux

(-)-angustureine (82\%)

When the allyl bromide bears an ester functionality, the indium-promoted allylation of $\omega$-(2bromophenyl)imines gave the expected homoallylamines which after deprotection suffered two consecutive cyclizations yielding first a methylenelactam under basic conditions and then a copperpromoted $N$-arylation, affording finally bicyclic products (Scheme 30). ${ }^{31}$

Scheme 30

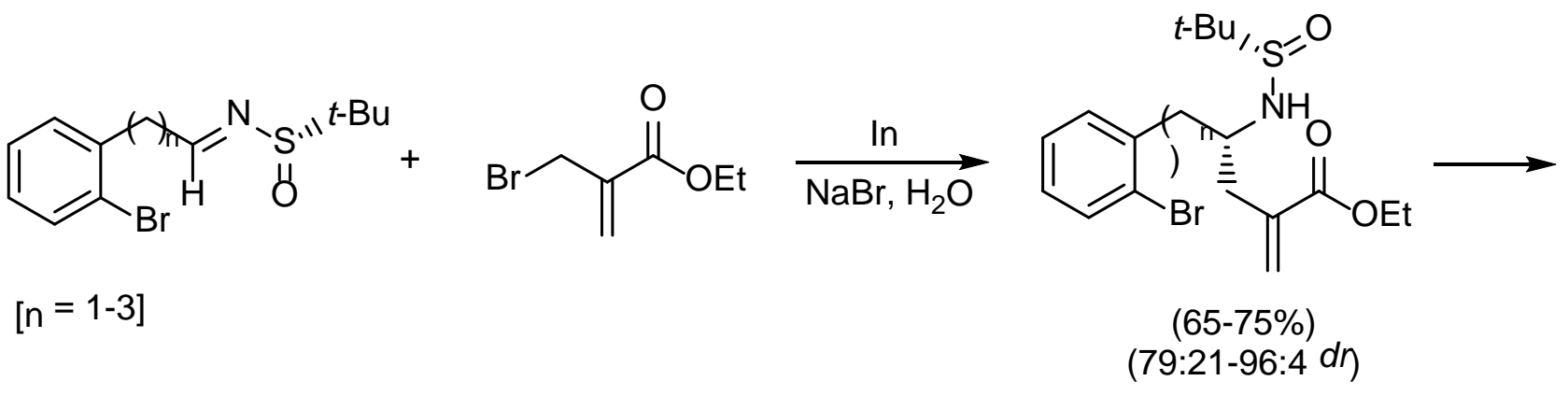

1) $\mathrm{HCl}-\mathrm{MeOH}$

2) $\mathrm{NaOMe}, \mathrm{MeOH}$<smiles>C=C1C[C@H](Cc2ccccc2Br)NC1=O</smiles>

$(75-94 \%)$<smiles>C=C1C[C@H]2Oc3ccccc3N2C(=O)C1CC(=O)OCc1ccccc1</smiles>

(27-54\%) 
A rather similar procedure was applied to the synthesis of another type of lactams containing an endocyclic double bond. Thus, the same starting materials were allylated and then deprotected to give a homoallylamine that was treated with acryloyl chloride followed by ring-closing metathesis. The obtained lactam was then treated with copper iodide to yield the corresponding bicyclic lactam, except for the seven-membered derivative $(n=3)$ (Scheme 31). ${ }^{31}$

\section{Scheme 31}
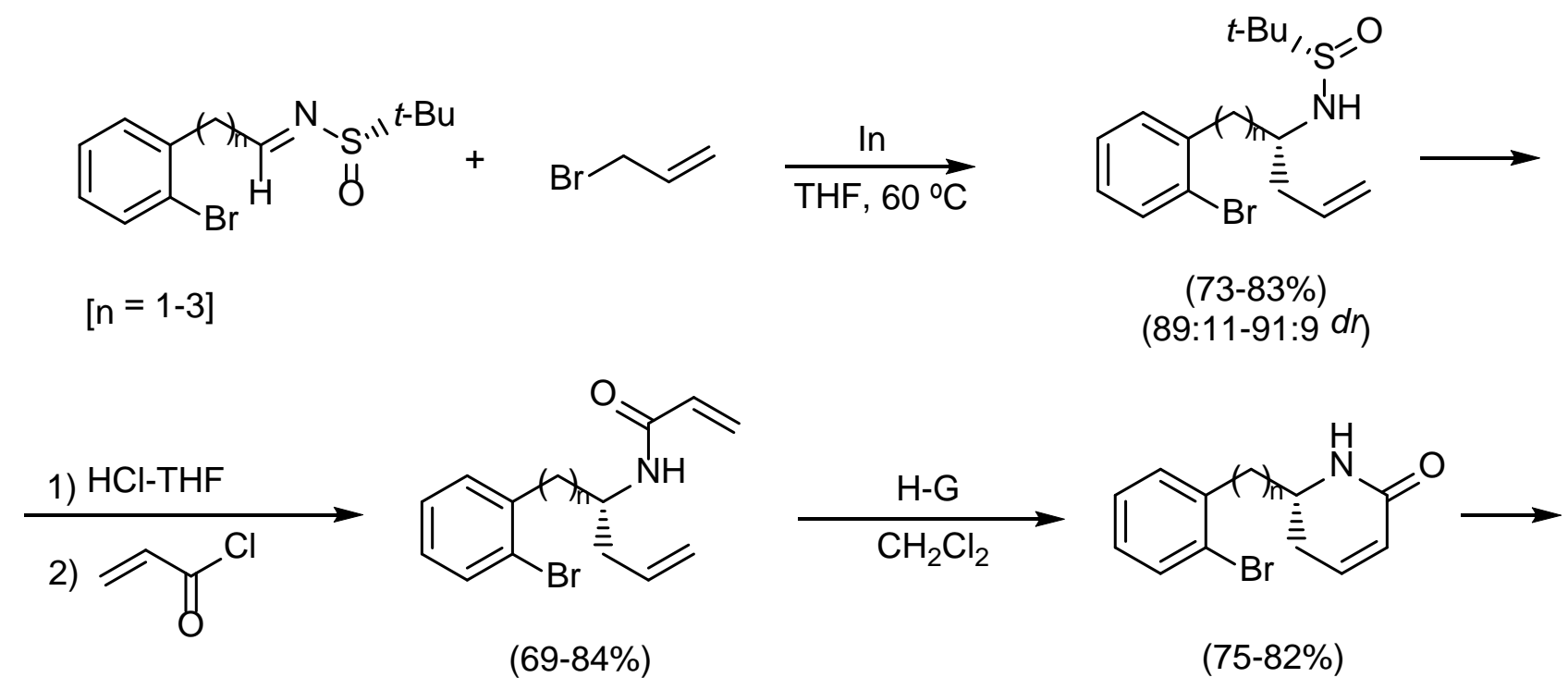

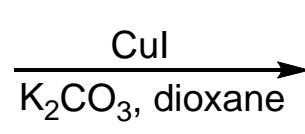<smiles>O=C1C=CC[C@@H]2Oc3ccccc3N12</smiles>

(83-90\%; $0 \%$ for $\mathrm{n}=3$ )

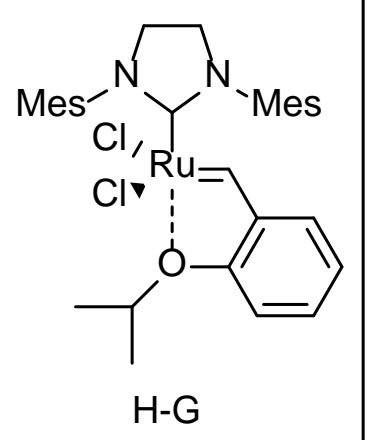

Recently we have been able to extend the allylation of aldimines to the corresponding ketimines. This reaction is particularly interesting because a quaternary stereocenter is created. Scheme 32 shows this process for both series of chiral ketimines. ${ }^{32}$ 
Scheme 32

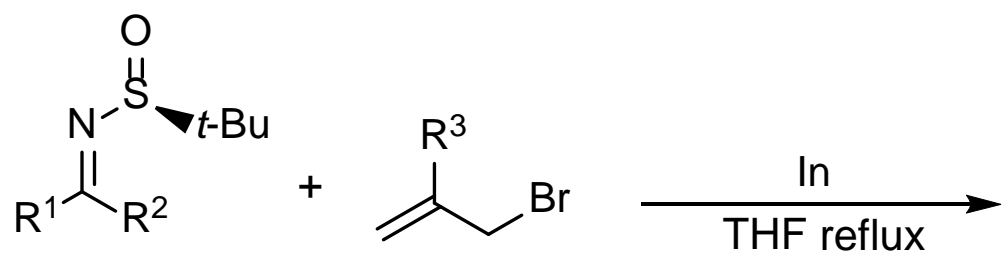

[15 examples]<smiles>[R15][13CH2]S(=O)NC([R2])([R])CC([R])=C</smiles>

$44-92 \%$

$(59: 41->98: 2 d \eta$

$$
\left[\begin{array}{l}
\mathrm{R}^{1}=\mathrm{Et}, i-\mathrm{Pr}, \mathrm{CH}_{2}=\mathrm{CH}, \mathrm{Me}\left(\mathrm{CH}_{2}\right) 4, \mathrm{Ph}, 2-\text { naphthyl } \\
\mathrm{R}^{2}=\mathrm{Me}, \mathrm{Et} \\
\mathrm{R}^{1}-\mathrm{R}^{2}=\left(\mathrm{CH}_{2}\right) \mathrm{nCH}=\mathrm{CH}(\mathrm{n}=2-4) \\
\mathrm{R}^{3}=\mathrm{H}, \mathrm{Me}
\end{array}\right.
$$

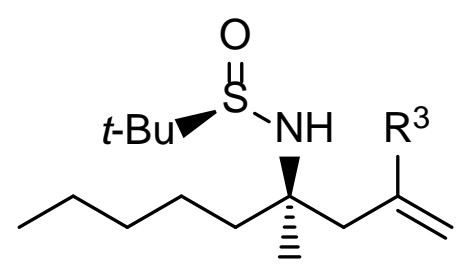

$78 \%$

$(>98: 2 d \eta$

Now, aldimines or ketimines derived from $\omega$-(2-bromophenyl) carbonyl compounds were allylated in the presence of indium and the resulting homoallylamines submitted to a Heck-type process to afford the corresponding chiral methylene bicyclic compounds, bearing the sulfinamide functionality (Scheme 32). ${ }^{32}$ 
<smiles>[R]C(Cc1ccc([X])cc1Br)=NS(=O)C(C)C</smiles>

$60-98 \%$

$$
\left[\begin{array}{l}
R=H, M e \\
n=0-3 \\
X=H, F, M e O
\end{array}\right]
$$<smiles>CC=CCBr</smiles>

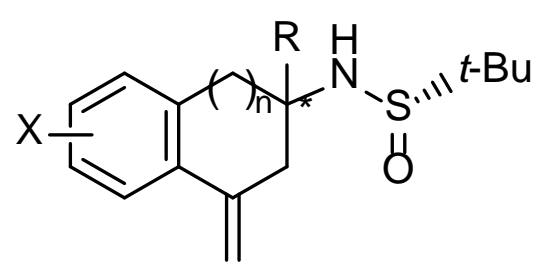

$56-100 \%$

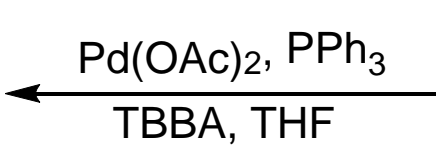

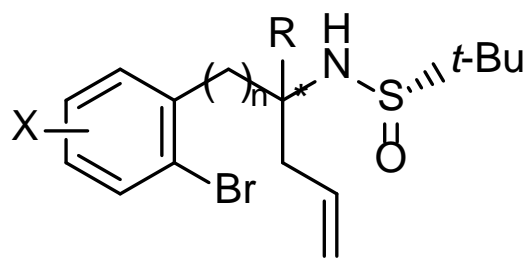

$16-94 \%$

$(60: 40->98: 2 d r)$

Chart 5 shows some of the products prepared, having five, six or seven membered structures. As it can be see, deprotection under acidic conditions yielded the expected primary amines with excellent yield. ${ }^{32}$

\section{Chart 5}<smiles>C=C1CCc2ccccc21</smiles>

$62 \%$<smiles>C=C1C[C@H](NS(=O)C(C)(C)C)c2ccccc21</smiles>

$62 \%$<smiles>C=C1C[C@H](NS(=O)C(C)(C)C)Cc2ccccc21</smiles>

$80 \%$<smiles>C=C1C[C@H](NS(=O)C(C)(C)C)CCc2ccccc21</smiles>

$70 \%$<smiles>C=C1C[C@H](N)c2ccccc21</smiles>

$93 \%$<smiles>C=C1C[C@](C)(NS(=O)C(C)(C)C)c2ccccc21</smiles>

$100 \%$<smiles>C=C1C[C@](C)(NS(=O)C(C)(C)C)Cc2ccccc21</smiles>

$72 \%$<smiles>C=C1C[C@](C)(NS(=O)C(C)(C)C)CCc2ccccc21</smiles>

$68 \%$

Finally, the indium-promoted propargylation was studied for chiral aldimines and ketimines using silylated propargyl bromide under sonication to afford the corresponding homopropargylamines without detecting any trace of the possible allenyl derivatives (Scheme 33). ${ }^{33}$ 
Scheme 33

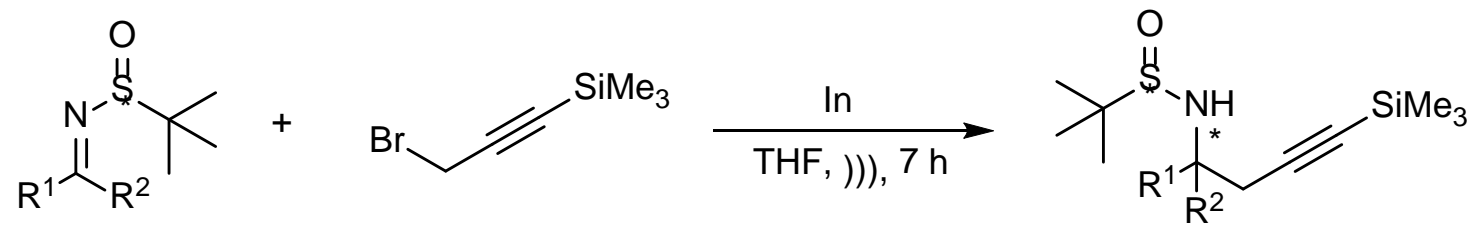

[15 examples] $\quad 47-80 \%$

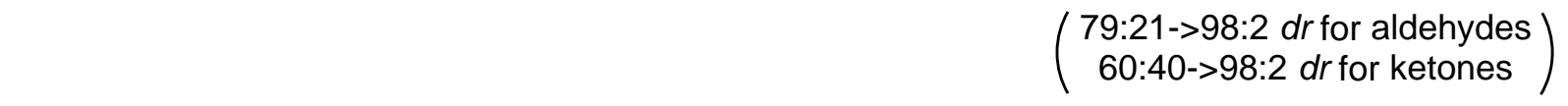<smiles>CCCCCCCC[C@H](CC#C[SiH3])NS(=O)C(C)(C)C</smiles>

$57 \%$

$(>98: 2 d r)$<smiles>CCCCC[C@](C)(CC#C[As])N[S@](=O)C(C)(C)C</smiles>

$63 \%$

$(>98: 2 d n)$

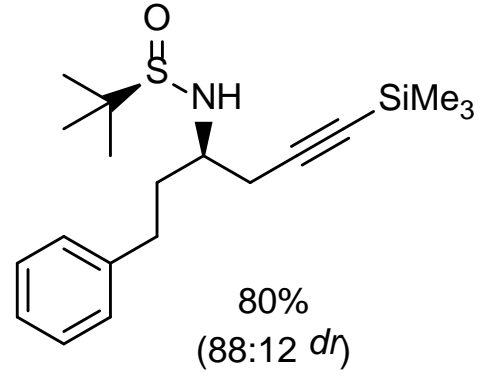
$\mathrm{SiMe}_{3}$

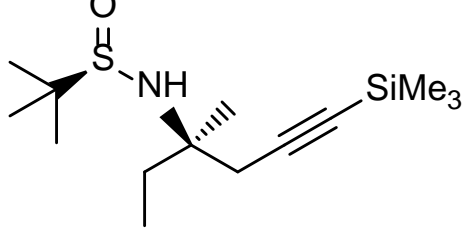

$52 \%$ $(>98: 2 d \eta$<smiles>CSC#CC[C@H](NS(=O)C(C)(C)C)c1ccccc1Br</smiles>

$63 \%$

$(88: 12 d \eta$<smiles>CC(C)C#CC[C@]1(N[S@](=O)C(C)(C)C)C=CCCC1</smiles>

$67 \%$

$(75: 25 d \eta$ 
Scheme 34 shows an explanation of the observed regio- and stereochemistry: The initially formed propargyl indium intermediate is in equilibrium with the allenyl one. This is the most stable organoindium reagent, which through a cyclic transition state forces a $\gamma$-attack in the reaction with the imine. On the other hand, the observed stereochemistry can be easily explained considering that the allenyl indium intermediate reacts at the $S i$ face of the imine with $R$-configuration at the sulphur atom, an interaction of the indium atom with the sulfinamide moiety fixing the corresponding topicity (Scheme 34). The orthogonal deprotection of the obtained homopropargyl amines could be perform under basic or acidic conditions giving the expected terminal alkynes or the primary amines, respectively. ${ }^{33}$ 

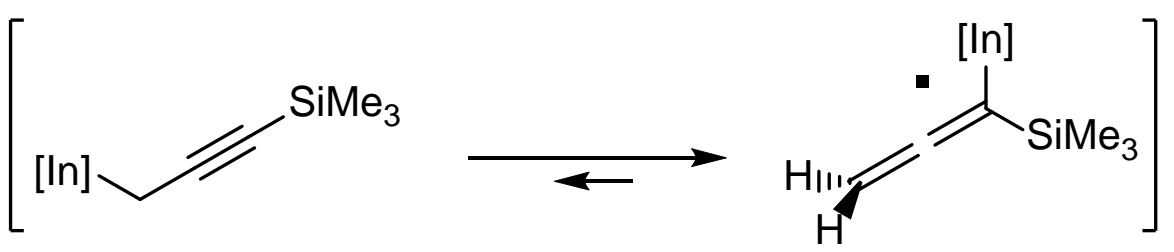

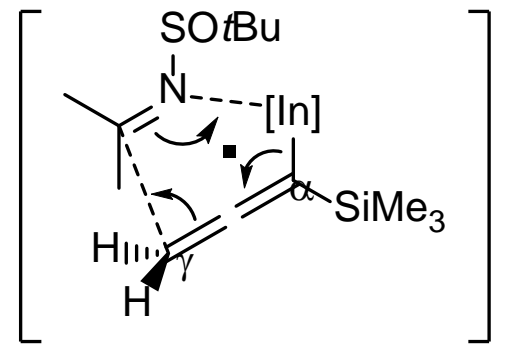

$\gamma$-regiochemistry

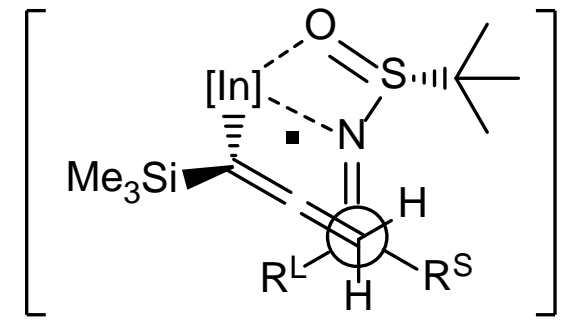

Si-face sterochemistry for $R_{\mathrm{S}}$ imines<smiles>CSC#CC[C@H](CCc1ccccc1)NS(=O)C(C)(C)C</smiles>
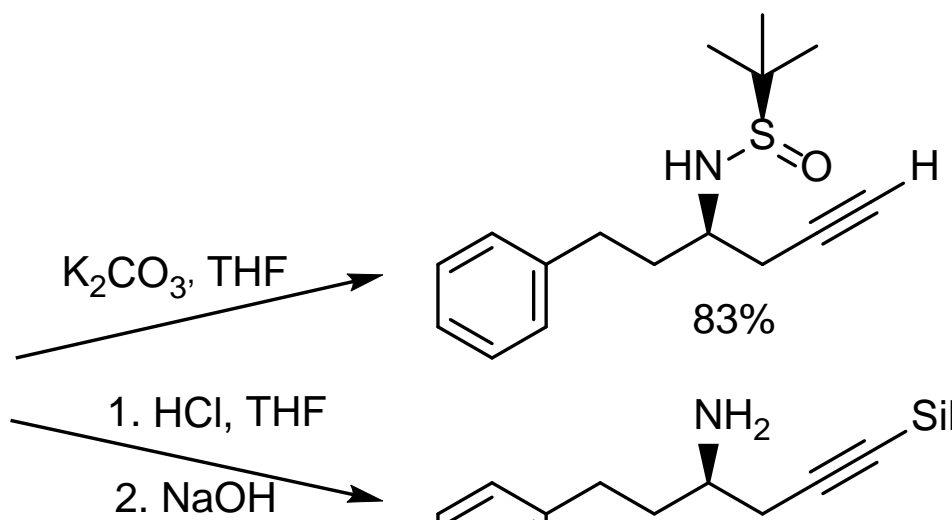<smiles>CSC#CC[C@H](N)CCc1ccccc1</smiles>

\section{Multicomponent reactions}

Years ago, the conjugate addition of a dialkylzinc reagent to cyclohexenone following by trapping of the generated zinc enolate with an aldehyde has been reported. The asymmetric version of this process with a BINOL-derived phosphoramidate was also developed (Scheme 35). ${ }^{34}$ 

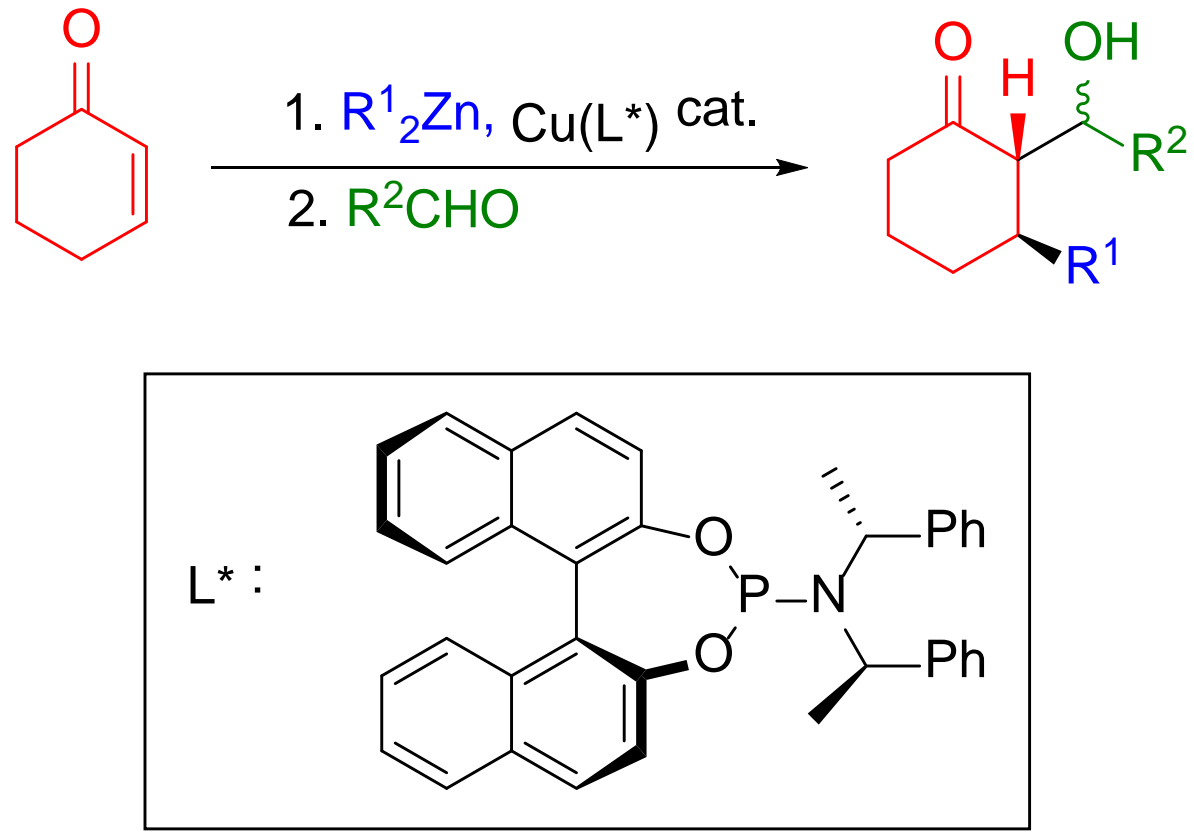

With these antecedents we decided to apply this reaction to chiral $\mathrm{N}$-(tertbutylsulfinyl)imines as the electrophilic component. Thus, the multicomponent reaction in the presence of a catalytic amount of copper triflate yielded only one diastereomer of the corresponding ketimine (Scheme 36). ${ }^{35}$

\section{Scheme 36}

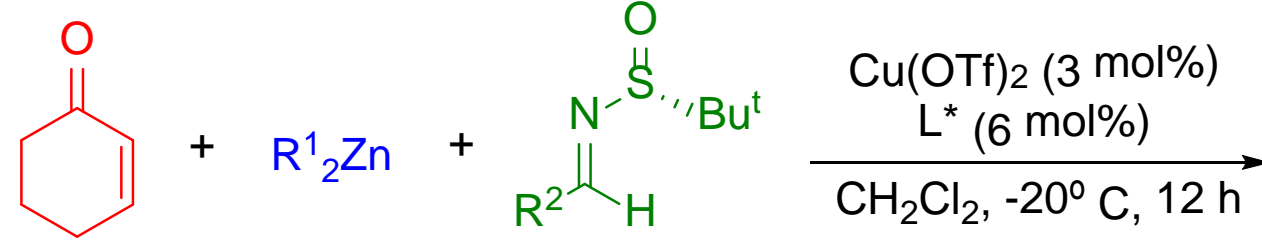

[12 examples]<smiles>[R]C1CCCC(=O)[C@H]1C([R])N([R])[S@](=O)Br</smiles>

$25-92 \%$

(one diastereomer)<smiles>C[C@@H](c1ccccc1)N([C@@H](C)c1ccccc1)P(Oc1ccccc1)Oc1ccc2ccccc2c1</smiles>

We observed that the stereochemistry at the ring is always trans, the absolute configuration being controlled by the chiral ligand. On the other hand, the stereochemistry of the carbon-nitrogen bond is controlled by the stereochemistry of the sulphur atom in the starting aldimines. By this way, 
it is possible to determine previously the final stereochemistry by considering the stereocenters of the ligand and the starting imines (Scheme 37). ${ }^{35}$

\section{Scheme 37}<smiles>CC[C@H]1CCCC(=O)[C@H]1[C@H](NS(=O)Cc1ccccc1)c1ccccc1</smiles>

$75 \%(>95: 5 d \eta$<smiles>CCC1CCCC(=O)C1[C@@H](NS(=O)CBr)c1ccccc1</smiles>

$75 \%(>95: 5 d \eta$
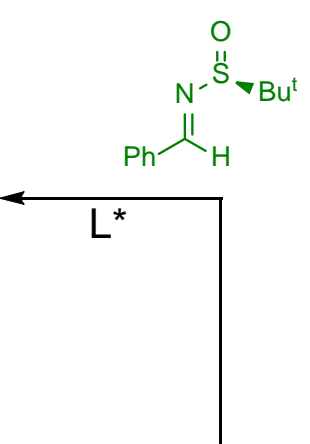

$\int$<smiles>O=C1C=C[CH+]CC1</smiles><smiles>CC[Te]</smiles>
$\mathrm{Cu}(\mathrm{OTf})_{2}$ cat.

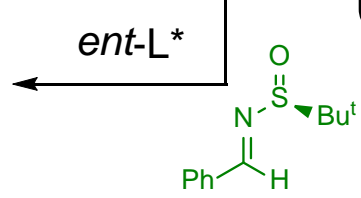

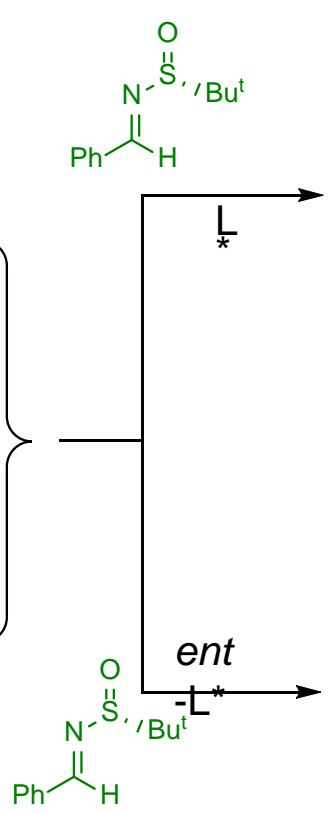

70\% (91:9 $d r)$

Chart 5 shows the score of this process considering several dialkylzinc reagents, as well as different aldimines. ${ }^{35}$

\section{Chart 5}


<smiles>CCCCS(=O)N([Hg])[C@@H](CCPc1ccccc1)[C@@H]1C(=O)CCC[C@@H]1C</smiles>

$92 \%$<smiles>[CH][S@@](=O)N([Hg])[C@@H](CCPc1ccccc1)[C@@H]1C(=O)CCC[C@@H]1CC</smiles>

$86 \%$<smiles>CCS(=O)N([Hg])[C@@H](CCPc1ccccc1)[C@H]1C(=O)CCC[C@@H]1P</smiles>

$80 \%$<smiles>CC(C)(C)[SH](=O)N([C@@H](CCPc1ccccc1)[C@H]1C(=O)CCC[C@@H]1c1ccccc1)S(=O)(=O)c1ccccc1</smiles>

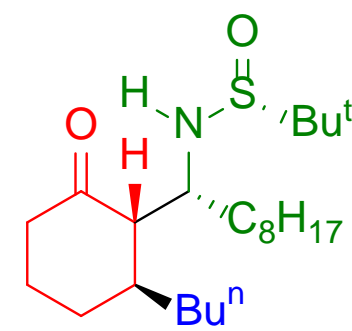

$65 \%$<smiles>CC(C)CS(=O)N([Hg])[C@@H](/C=C/c1ccccc1)[C@@H]1C(=O)CCC[C@@H]1C</smiles>

$60 \%$<smiles>CC[C@H]1CCCC(=O)[C@H]1[C@@H](c1ccccc1)N(c1ccccc1)[S@@](=O)C(C)(C)C</smiles>

$65 \%$

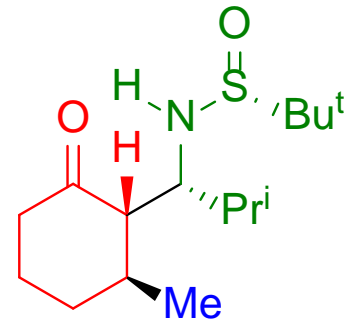

$25 \%$

The same process was also applied to cyclopentenone, the reaction being in this case not so selective compared to the reaction starting from cyclohexenone. In this case a trans configuration was also observed but with different configuration than for cyclohexenone (Scheme 38). ${ }^{35}$

Scheme 38

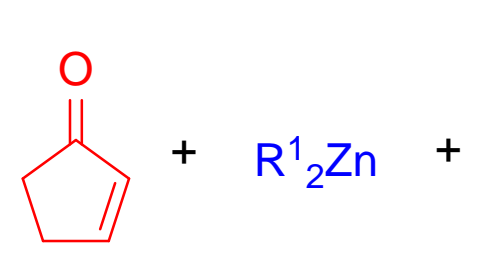<smiles>[R]/C=N\S([15CH])=O</smiles>

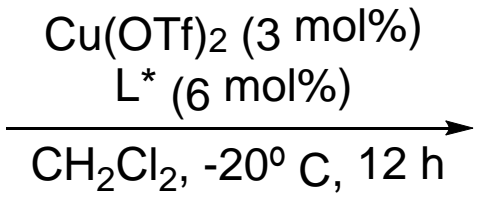

[7 examples]<smiles>[R]C1CCC(=O)[C@H]1C([R2])NS(=O)[Ba]</smiles>

$24-83 \%$

$(70: 30->95: 5 d \eta$

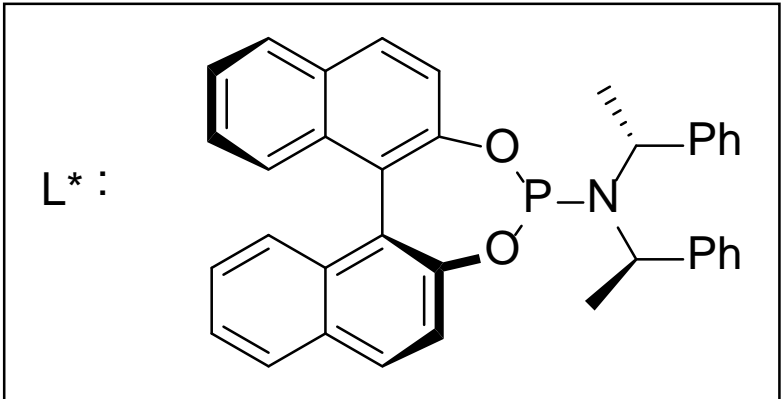

Chart 6 shows a few examples of the process depicted in Scheme 38. 


\section{Chart 6}<smiles>CC[C@H]1CCC(=O)[C@@H]1[C@H](CCc1ccccc1)NS(=O)[Ba]</smiles>

$82 \%(85: 15 d \eta)$<smiles>O=C1CC[C@@H](P)[C@H]1[C@H](CCc1ccccc1)NS(=O)[Ba]</smiles>

81\% (>95:5 dr)<smiles>O=[10B]S(=O)N[C@H](c1ccccc1)[C@H]1C(=O)CC[C@@H]1P</smiles>

$83 \%(94: 6 d \eta)$<smiles>O=C1CC[C@@H](P)[C@H]1[C@H](/C=C/c1ccccc1)NS(=O)[Ba]</smiles>

79\% (84:14dn)<smiles>[CH][S@@](=O)N[C@@H](c1ccc(OC)cc1)[C@@H]1C(=O)CC[C@H]1P</smiles>

78\% (98:11 dn)<smiles>O=C1CC[C@H](P)[C@@H]1[C@H](P)NS(=O)[Ba]</smiles>

$24 \%(>95: 5 d r)$

Finally, the application of this methodology to cycloheptenone gave one only diastereomer, the stereochemistry being the same as that observed for cyclohexenone depicted in Scheme 36 (Scheme 39). ${ }^{35}$ 


\section{Scheme 39}

${ }^{H}+\mathrm{R}^{1}{ }_{2} \mathrm{Zn}+\mathrm{R}^{2} \mathrm{~N}_{\mathrm{H}}^{\mathrm{N}}$

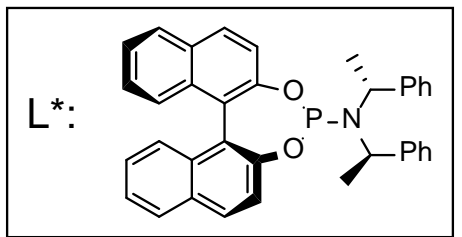<smiles>C[C@H]1CCCCC(=O)[C@H]1[C@H](CCc1ccccc1)NS(=O)Br</smiles>

$86 \%$<smiles>CCCCS(=O)NC(c1ccccc1)[C@]1(c2ccccc2)C(=O)CCCC[C@@H]1CC</smiles>

$66 \%$<smiles>CCC1CCCCC(=O)[C@H]1[C@H](CCCC(C)=O)NS(=O)CC</smiles>

$85 \%$

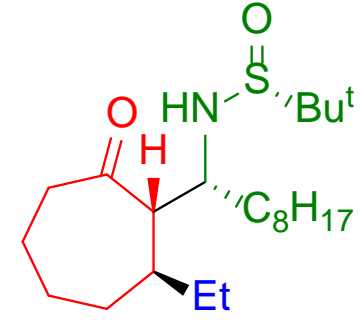

$66 \%$

\section{Conclusions}

Through this account it can be seen that chiral $N$-(tert-butyl)sulfinyl imines are excellent reagents for the asymmetric synthesis of several nitrogen-containing compounds by reaction with electrophiles, among them hydrogen (by a hydrogen transfer), zincates, allylindium intermediates and zinc enolates. The obtained products are easily desulfinylated under acidic conditions. This methodology allows the asymmetric preparation of a number of natural alkaloids and other derivatives.

\section{Acknowledgements}

We thank the continuous financial supportfrom ur Ministerio de Ciencia e Innovación (MICINN; projects CTQ2007-62771/BQU, CTQ2010-20387, CONSOLIDER INGENIO 2010CDS2007-00006, CTQ2011-24151, CTQ20122-24165), the Ministerio de Economía y Competitividad (MINECO; projects CTQ2013-43446-P, CTQ2014-51912-REDC, CTQ201453695-P), FEDER, the Generalitat Valenciana (PROMETEOII/2014/017), and the University of Alicante.

\section{References}

1. MDL Drug Data Report, MDL Information Systems, Inc., CA. 
2. (a) D. A. Cogan, G. Liu, and J. Ellman, Tetrahedron, 1999, 55, 8883; (b) J. A. Ellman, T. D. Owens, and T. P. Tang, Acc. Chem. Res., 2002, 35, 984; (c) J. A. Ellman, Pure Appl. Chem., 2003, 75, 39.

3. (a) R. Noyori and S. Hashiguchi, Acc. Chem. Res., 1997, 30, 97; (b) M. J. Palmer and M. Wills, Tetrahedron: Asymmetry, 1999, 10, 2045; (c) C. Wang, X. Wu, and J. Xiao, Chem Asian J., 2008, 3, 1750; (d) F. Foubelo, C. Nájera, and M. Yus, Tetrahedron: Asymmetry, 2015, 26, 769.

4. (a) S. Kobayashi and H. Ishitani, Chem. Rev., 1999, 99, 1069; (b) G. Helmchen and A. Pfaltz, Acc. Chem. Res., 2000, 33, 336; (c) M. Wills, in Modern Reduction Methods, Eds. P. G. Andersson and I. J. Munslow, Wiley-VCH, Weinheim, 2008, p. 271; (d) F. Foubelo and M. Yus, Chem. Rec., 2015, 15, 907.

5. (a) G. Liu, D. A. Cogan, T. D. Owens, T. P. Tang, and J. A. Ellman, J. Org. Chem., 1999, 64, 1278; (b) J. F. Collados, E. Toledano, D. Guijarro, and M. Yus, J. Org. Chem., 2012, 77, 5744.

6. M. Wills, M. Palmer, A. Smith, J. Kenny, and T. Walsgrove, Molecules, 2000, 5, 4.

7. (a) D. Guijarro, O. Pablo, and M. Yus, Tetrahedron Lett., 2009, 50,5386; (b) D. Guijarro, O. Pablo, and M. Yus, J. Org. Chem., 2010, 75, 5265 (Synfacts, 2010, 1254).

8. (a) D. Guijarro, O. Pablo, and M. Yus, Tetrahedron Lett., 2011, 52, 789 (Synfacts, 2011, 508);

(b) O. Pablo, D. Guijarro, G. Kovács, A. Lledós, G. Ujaque, and M. Yus, Chem. Eur. J., 2012, 18, 1969; (c) D. Guijarro, O. Pablo, and M. Yus, Org. Synth., 2013, 90, 338.

9. D. Guijarro, O. Pablo, and M. Yus, J. Org. Chem., 2013, 78, 3647.

10. O. Pablo, D. Guijarro, and M. Yus, J. Org. Chem., 2013, 78, 9181.

11. M. Yus and D. J. Ramón, Recent Res. Dev. Org. Chem., 2002, 6, 297.

12. D. J. Ramón and M. Yus, Angew. Chem. Int. Ed., 2004, 43, 284.

13. (a) R. Almansa, D. Guijarro, and M. Yus, Tetrahedron: Asymmetry 2008, 19, 603; (b) R. Almansa, D. Guijarro, and M. Yus, Tetrahedron: Asymmetry 2008, 19, 2484.

14. R. Almansa, D. Guijarro, and M. Yus, Tetrahedron Lett., 2009, 50, 3198.

15. (a) R. Almansa, D. Guijarro, and M. Yus, Tetrahedron Lett., 2009, 50, 4190; (b) R. Almansa, J. F. Collados, D. Guijarro, and M. Yus, Tetrahedron:Asymmetry., 2010, 21, 1421.

16. (a) S. Kobayashi and H. Ishitani, Chem. Rev., 1999, 99, 1069; (b) G. Alvaro and D. Savoia, Synlett, 2002, 651.

17. (a) M. Yus, J. C. González-Gómez, and F. Foubelo, Chem. Rev., 2011, 111, 7774; (b) M. Yus, J. C. González-Gómez, and F. Foubelo, Chem. Rev., 2013, 113, 5595.

18. (a) F. Foubelo and M. Yus, Tetrahedron: Asymmetry, 2004, 15, 3823; (b) J. C. GonzálezGómez, M. Medjahdi, F. Foubelo, and M. Yus, J. Org. Chem., 2010, 75, 6308.

19. F. Foubelo and M. Yus, Eur. J. Org. Chem., 2014, 485.

20. D. J. Ramón and M. Yus, Angew. Chem. Int. Ed., 2005, 44, 1602.

21. J. C. González-Gómez, F. Foubelo, and M. Yus, Org. Synth., 2012, 89, 88.

22. J. C. González-Gómez, F. Foubelo, and M. Yus, Synlett, 2008, 2777.

23. M. Medjahdi, J. C. González-Gómez, F. Foubelo, and M. Yus, Heterocycles, 2012, 86, 727.

24. S. E. Schaus, B. D. Brandes, J. F. Larrow, M. Tokunaga, K. B. Hansen, A. E. Gould, M. E. Forrow, and E. N. Jacobsen, J. Am. Chem. Soc., 2002, 124, 1307.

25. (a) M. Medjahdi, J. C. González-Gómez, F. Foubelo, and M. Yus, Heterocycles, 2008, 76, 569; (b) M. Medjahdi, J. C. González-Gómez, F. Foubelo, and M. Yus, J. Org. Chem., 2009, 74, 7859. 
26. (a) H. K. Dema, F. Foubelo, and M. Yus, Heterocycles, 2010, 80, 125; (b) H. K. Dema, F. Foubelo, and M. Yus, Heterocycles, 2011, 82, 1411.

27. I. Bosque, J. C. González-Gómez, F. Foubelo, and M. Yus, J. Org. Chem., 2012, 77, 780; corrigendum: J. C. Bosque, J. C. González-Gómez, F. Foubelo, and M. Yus, J. Org. Chem., 2012, 77, 4190.

28. I. Bosque, J. C. González-Gómez, A. Guijarro, F. Foubelo, and M. Yus, J. Org. Chem., 2012, 77, 10340.

29. M. Medjahdi, J. C. González-Gómez, F. Foubelo, and M. Yus, Eur. J. Org. Chem., 2011, 2230.

30. J. A. Sirvent, F. Foubelo, and M. Yus, Heterocycles, 2014, 88, 1163.

31. J. A. Sirvent, F. Foubelo, and M. Yus, J. Org. Chem., 2014, 79, 1356.

32. J. A. Sirvent, F. Foubelo, and M. Yus, Chem. Commun., 2012, 48, 2543.

33. J. A. Sirvent, F. Foubelo, and M. Yus, Eur. J. Org. Chem., 2013, 2461.

34. (a) M. Kitamura, T. Miki, K. Nakano, and R. Noyori, Tetrahedron Lett., 1996, 37, 5141; (b) B. L. Feringa, M. Pineschi, L. A. Arnold, R. Imbos, and A. H. de Vries, Angew. Chem. Int. Ed., 1997, 36, 2620; (c) A. Alexakis and C. Benhaim, Eur. J. Org. Chem., 2002, 3221.

35. (a) J. C. González-Gómez, F. Foubelo, and M. Yus, Tetrahedron Lett., 2008, 49, 2343 (Synfacts, 2009, 2547); (b) J. C. González-Gómez, F. Foubelo, and M. Yus, J. Org. Chem., 2009, 74, 2547. 